\title{
ORIR EN FEMENINO: LA CONSTRUCCIÓN SIMBÓLICA EN LAS EXEQUIAS FÚNEBRES DE MARÍA JOSEFA AMALIA DE SAJONIA
}

\author{
ESTER ALBA PAGÁN \\ Universitat de València \\ esther.alba@uv.es
}

\begin{abstract}
Resumen: Este artículo ofrece un análisis de la construcción simbólica de la reina María Josefa Amalia de Sajonia, tercera esposa de Fernando VII, a través de sus exequias fúnebres celebradas en España en 1829. A través de los textos impresos de las Relaciones, Oraciones fúnebres y textos poéticos nos adentramos en el lenguaje hiperbólico que en ellos se ofrecía de la difunta, mientras que las Descripciones de las fiestas y de los cenotafios o túmulos funerarios, así como los grabados que se conservan de estos nos plantean en qué medida el lenguaje artístico contribuyó a fabricar el concepto de la reina doméstica frente a la antigua imagen de la reina cortesana, en la crisis del Antiguo Régimen. En este sentido, la intención no es la de ilustrar un discurso teórico con obras de arte, sino reflexionar a través de las obras de arte. Las ceremonias y el arte efímero presentan una trascendencia pública diferenciada que alcanzó a las capas populares. En el caso de las exequias de María Josefa Amalia, la aparición de la nueva técnica de estampación, la litografía, generará un número inusitado de grabados, especialmente en las ciudades de Barcelona, Valencia y otras ciudades del antiguo reino de la Corona de Aragón, junto a las producidas en la Corte. La popularización de esta técnica, más sencilla y menos costosa, propiciará que muchas instituciones u organismos acompañen sus textos impresos de imágenes de sus monumentos levantados.
\end{abstract}

Palabras clave: María Josefa Amalia de Sajonia / exequias / reina / arte efímero.

\section{TO DIE IN FEMININE: THE SYMBOLIC CONSTRUCTION IN THE FUNERAL SERVICES OF MARÍA JOSEFA AMALIA DE SAJONIA}

\begin{abstract}
This article offers an analysis of the symbolic construction of Queen María Josefa Amalia de Sajonia, third wife of Ferdinand VII, through her funeral services held in Spain in 1829. Through the printed texts of Relationships, Funeral Prayers and poetic texts, we delve into the hyperbolic language that was offered in them of the deceased, while the Descriptions of the festivals and of the cenotaphs or burial mounds, as well as the engravings that are preserved of these, show us to what extent the artistic language contributed to fabricate the concept of the domestic queen in front of the old image of the courtesan queen, in the crisis of the Old Regime. In this sense, the intention is not to illustrate a theoretical discourse with works of art, but to reflect through works of art. Ceremonies and ephemeral art present a differentiated public significance that reached the popular layers. In the case of the funeral of María Josefa Amalia, the appearance of the new printing technique, lithography, will generate an unusual number of engravings, especially in the cities of Barcelona, Valencia and other cities of the old kingdom of the Crown of Aragon. along with those produced in the Court. The popularization of this technique, which is simpler and less expensive, will encourage many institutions or organizations to accompany their printed texts with images of their raised monuments.
\end{abstract}

Key words: María Josefa Amalia de Sajonia / funeral / queen / ephemeral art.

\section{La reina en el discurso proyectado}

El fin del absolutismo y la irrupción del liberalismo en el panorama político español generó una verda- dera batalla dialéctica de imágenes y apropiaciones. Por ello, durante los últimos años del reinado de Fernando VII, precisamente aquellos que correspon-

* Fecha de recepción: 15 de abril de 2020 / Fecha de aceptación: 20 de octubre de 2020. 
den a los de un control político férreo en la llamada década ominosa, resulta interesante analizar los recursos simbólicos que la monarquía absolutista utilizó, en los últimos años de su existencia, como herramienta de propaganda a través de la que proyectar la imagen de la monarquía entre la población. Para ello, las fiestas efímeras que tenían un amplio calado popular y traspasaban la jerarquía social son una fuente importante a través de las que analizar las estrategias de persuasión utilizadas por los resortes políticos al servicio de la realeza. En este mundo, el ceremonial, la expresión máxima del arte efímero y del lenguaje simbólico asociado a la monarquía, destaca a través de la celebración de las exequias fúnebres organizadas en honor del monarca, la reina o los miembros difuntos de la familia real. Estos estudios de la llamada performing monarchy, monarquía ceremonial o escénica, han ido cobrando, en los últimos años, interés al analizar este proceso legitimador teniendo en cuenta no solo los valores instrumentales y simbólicos sino también el carácter horizontal que afectaba por igual a las élites y a las clases populares locales, de acuerdo a las nuevas jerarquías de valores. ${ }^{1}$ Asociados a esta planificación de grandes espectáculos ceremoniales aparecen elementos de una diseminación continua, soterrada y cotidiana: canciones, elaboraciones satíricas, rumores, y grabados formaron parte de los mecanismos informales difusión social, cultural y política del discurso monárquico en los primeros tiempos de la contemporaneidad. Así, la imagen de la monarquía alcanzó a todos los niveles sociales y fue fruto de la fabricación ideada y elaborada por los más renombrados artistas cortesanos y, fuera de la Corte, por artistas locales de renombre, en decoraciones alegóricas e históricas, en murales, retratos y decoraciones efímeras; pero los grabados, como medio de difusión popular, jugaron un papel significativo por su gran poder co- municativo, especialmente gracias al desarrollo de la nueva técnica de la litografía.

El sentido de la "trascendencia pública diferencia$\mathrm{da}^{\prime 2}$ es una de las cuestiones presentes en las ceremonias fúnebres asociadas a la élite social, especialmente a la monarquía, en las que la participación popular de los súbditos resulta fundamental para analizar la recepción de los poemas, relaciones, oraciones fúnebres, y de los grabados en los que se mostraban decoraciones efímeras y monumentos, cuando no de los propios aparatos efímeros y su lenguaje alegórico cargado de fuerte significación. Si bien es cierto, que en gran número de publicaciones relacionadas con el arte efímero del barroco se insiste en considerar las fiestas y celebraciones como instrumentos de control y de propaganda, ${ }^{3}$ en realidad hemos de poner cierta distancia sobre la verdadera efectividad ideológica de estos eventos sociales, especialmente a partir del XIX y durante el reinado de Fernando VII, cuando la dialéctica liberal y absolutista se enfrenta en una batalla de imágenes y símbolos reapropiados continuamente. ${ }^{4}$ Precisamente analizar los discursos emergentes desde la óptica del mensaje que se deseaba trasladar a la población, en la construcción o fabricación de la imagen, en este caso de la reina, resulta tanto o más interesante que su recepción pública, pues constituye el núcleo central que vehiculará su rechazo o aceptación. ${ }^{5}$

Es en el acto de proclamación y en sus exequias en los que la reina fue elevada sin parangón a su imagen simbólica. ${ }^{6}$ Resulta, pues, necesario analizar los cambios en la imagen proyectada de la monarquía entre finales del siglo XVIII y principios del XIX para entender la complejidad de una institución que se resistía a su transformación, pero que, sin embargo, realizó mutaciones conducentes a proveer un mayor acercamiento de la institución a la sociedad.

\footnotetext{
1 En el ámbito europeo han sido múltiples los estudios que han abordado ese cambio en el que los viejos lenguajes, tradiciones y símbolos son reelaborados y reorganizados en el siglo XIX, como así demuestran BILLING, Michael; VAN OSTA, Jaap, 2007; UNOWSKY, Daniel L., 2005; BRICE, Catherine, 2010 y más recientemente FITZPATRICK, Matthew P., 2018.

2 DOMÉNECH, Albert, 2018, p. 223.

3 Por ello, aunque es cierto, como ha elucidado KLÉBER MONOD, Paul, 1999 que la institución monárquica fue pensada tradicionalmente en términos masculinos, resulta necesario, como defiende FRADENBURG, Olga, 1992 que los estudios sobre el poder monárquico, y en general sobre las fórmulas de representación del poder, incluyan estudios sobre el papel de las reinas o seguirán siendo inadecuados si no se analiza la forma en que la propia noción de soberanía real incluye connotaciones de género.

${ }^{4}$ GARGANTÉ, Maria, 2011, p. 35-36: "I'assistència massiva als actes era programada mitjançant anuncis i fins i tot amb la prohibició de treballar en aquells dies o durant les hores centrals de la celebració sota pena de multes -fet que indica que potser existia alguna mena de resistència. (...) Així, l'assistència als actes públics s'havia de magnificar com a prova de la legitimitat dels principis polítics i socials de l'ordre imperant".

5 PÉREZ SAMPER, María Ángeles, 2005, p. 275 y 307.

${ }^{6}$ LANDES, Joan B., 1998.
} 
Dentro de este enfoque resulta sumamente interesante el libro de Nochlin, Women, Art and Power, and other essays, ${ }^{7}$ por su planteamiento de género en el contexto de la historia cultural. En este ensayo se preocupó especialmente por la representación visual que, en el caso de la perspectiva de género, afectaba de manera desigual a hombres y mujeres. Esta línea de la representación de la mujer como vehículo de difusión ideológica, al analizar sus imágenes como resultado de la jerarquía de relaciones de poder entre los sexos y la construcción de un discurso de roles acorde a cada uno, ${ }^{8}$ cuestionaba el papel otorgado por la historiografía tradicional a las reinas y establecía una relectura de la imagen proyectada comprensible desde el análisis cultural, al adaptarse la función retórica de la imagen al discurso político; pero que no debe verse como una lectura fidedigna de las diferentes corrientes de pensamiento, sino que se debe analizar como constructo de los argumentos políticos, en tanto que instrumentos ideológicos. ${ }^{9}$

Desde el punto de vista metodológico, ${ }^{10}$ estas aproximaciones son el inicio de una perspectiva nueva en el análisis de la fabricación artística de las reinas; que en nuestro caso puede aplicarse a la construcción de la imagen una de las últimas reinas del absolutismo español: la reina María Josefa Amalia de Sajonia, tercera esposa de Fernando VIl; concretamente a través de los funerales y exequias que en su honor se celebraron en 1829, año de su fallecimiento. Las exequias celebradas tras la muerte de María Josefa Amalia de Sajonia ofrecen un espejo claro a través del que analizar las transformaciones y las resistencias de una monarquía que se resistía al cambio. Uno de los episodios más interesantes, en este sentido, es el que vivió la joven reina al poco de llegar a España. Apenas se había aclimatado a la nueva corte cuando el pronunciamiento de Riego y la proclamación de la Constitución de 1812 estable- cieron un nuevo panorama político al que la soberana no parecía saber o nadie le explicó qué cambios en su comportamiento cortesano se requerían:

Convertida en la primera reina constitucional española, nadie le explicó a María Josefa en qué consistía el cambio, ni cómo podía afectarle. Tampoco sabemos si relacionó su presente con los modelos de monarquías templadas que había estudiado, ni si abrigaba sospechas de que el modelo que representaba su esposo no era el más acorde con los tiempos. En cualquier caso, continuó comportándose como hasta entonces, es decir, considerando el palacio su casa e interrumpiendo al rey, su esposo, mientras despachaba con los ministros, para saludarle o hacerle alguna consulta, sin percatarse de que las formas habían cambiado. Porque sus entradas, que obligaban a todos los asistentes a retirarse hasta ser llamados de nuevo, provocaban un controlado malestar entre las nuevas autoridades. Y es que la identificación entre la figura pública y la privada del rey dejaba de tener efecto por el texto constitucional, que diferenciaba bien los dos planos y entendía el despacho no como una gracia sino como una exigencia del sistema recién establecido. ${ }^{11}$

Efectivamente, en su estudio sobre el papel de la reina María Josefa Amalia de Sajonia, López Cordón afirmaba: "no es fácil hablar de María Josefa Amalia de Sajonia, ni como reina ni como escritora. El desinterés y los tópicos rodean a un personaje, a cuyo mal conocimiento contribuyó no poco una vida demasiado breve. Una discreta princesa alemana que no dio herederos a Fernando VII y que entretuvo sus ocios con la pluma, escribiendo cartas, algunos relatos en prosa y muchas poesías, que los críticos han juzgado mediocres aunque, eso sí, siempre acordes con los gustos y formas de la época". ${ }^{12}$

No obstante, resulta de gran interés la riqueza simbólica y la instrumentalización política que de su imagen se hizo, especialmente a través de sus funerales.

\footnotetext{
7 NOCHLIN, Linda, 1989.

${ }^{8}$ Igualmente, son de enorme interés los estudios de Schulte, quien, en su The Body of the Queen establecía cuestionamientos múltiples: "How many "bodies" does a queen have? What is the significance of multiple "bodies"? How has the gendered body been constructed and perceived within the context of the European courts during the course of the past five centuries?" SCHULTE, Regina (ed.), 2006. Parte de sus hipótesis defendidas en trabajos anteriores: SCHULTE, Regina, 2002, p. 266-293. También es interesante la aportación de SMITH, Theresa, 2006.

9 ALBA, Ester; PÉREZ OCHANDO, Luis, 2015, p. 10.

10 Esta perspectiva ha gozado de gran predicamento fuera de nuestras fronteras, como muestra el relevante trabajo de LANDES, Joan B., 2001 y AGULHON, Maurice, 1979 sobre el modo en que las alegorías femeninas representadas en la Revolución Francesa fueron utilizadas como vehículos de deseo de cara al espectador-ciudadano, con la intención de que se vieran reconocidos en los nuevos valores del Estado-Nación, han dado pie a nuevas reflexiones sobre la definición política del Antiguo Régimen en los inicios de la etapa liberal.

11 LÓPEZ-CORDÓN, María Victoria, 2015b, p. 88.

12 Algunos de estos escritos se publicaron en vida de la reina; otros, lo hicieron después y, la mayoría, se conservan en copias manuscritas tanto en el Archivo del Palacio Real como en la Biblioteca Nacional: LÓPEZ-CORDÓN, María Victoria, 2015b, p. 83.
} 


\section{Prudente como Isabel la Católica, pacífica como Margarita de Escocia, y admirable como Isabel de Hungría: la imagen de la reina María Josefa Amalia de Sajonia ante su muerte}

El día 17 de mayo de 1829 acaeció, en Aranjuez, la muerte de María Josefa Amalia de Sajonia. En los numerosos Elogios se hace especial hincapié en el destino trágico del infortunado rey, que ya había visto morir a dos reinas. Las alusiones a la muerte de Isabel de Braganza son abundantes en las odas por la muerte de la segunda reina. La presencia de la primera esposa de Fernando, la princesa de Asturias, María Antonia de Nápoles, ${ }^{13}$ apenas se vislumbra en los escritos, y toda alusión anterior a 1814 sirve para recuperar, más de veinte años después, el mito de Fernando como rey deseado, cuyo destino había sido compartir los infortunios de su pueblo en aquellos aciagos años.

Durante el reinado de Fernando VII, las exequias tuvieron un gran protagonismo. En 1819 murieron Isabel de Braganza, su segunda esposa ${ }^{14}$ y sus padres Carlos IV y María Luisa de Parma, en Roma y en Nápoles respectivamente; $y$, ahora, lo hacía de nuevo su tercera esposa. Desde el punto de vista social, las exequias constituyeron para el aparato de propaganda del monarca un buen instrumento para transmitir determinados mensajes a la población, que se entretenía visitando los grandes artefactos arquitectónicos que constituían los catafalcos o túmulos que se levantaban en el interior de las iglesias, entre ricas decoraciones y luminarias. Hoy conocemos estas maquinarias efímeras gracias a la impresión de las diversas relaciones en las que se describen las ceremonias, así como los monumentos efímeros y sus decoraciones. Estas ceremonias iban acompañadas de varios textos diferenciados: los ser- mones fúnebres, normalmente escritos y leídos por eclesiásticos de prestigio y la relación de las exequias en la que se recoge la decoración del templo, la descripción del monumento y los rituales de la ceremonia y, en ocasiones, se incluía un repertorio poético o las oraciones dedicadas al difunto. ${ }^{15}$ Estas relaciones u oraciones fúnebres iban, a menudo, acompañadas de un grabado con la reproducción del túmulo funerario. Por ello, resulta de interés analizar aquellos monumentos y relaciones de las ciudades en las que había una cierta relación, como la que existía entre los antiguos reinos de la Corona de Aragón, especialmente Valencia, Barcelona, Mallorca, así como su relación con la Corte madrileña. Estas relaciones y oraciones eran impresas y tenían un público fiel, como muestra el anuncio de su venta en diarios de la época, o su distribución más allá del ámbito local. ${ }^{16}$

La construcción simbólica de la reina María Josefa Amalia tenía elementos propios que aludían esencialmente a su piedad y devoción católica; pero, no obstante, algunos de los elementos asociados a la reina como pieza clave de la institución monárquica hemos de ponerlos en relación con el discurso generado en torno a la figura del monarca y que ya habían sido utilizados durante la guerra de la Independencia y a su regreso en 1814. Por ello, algunas de las imágenes construidas tienen aspectos comunes con lo planteado en las exequias de sus dos esposas anteriores, ${ }^{17}$ en las que el estilo literario utilizado se caracteriza por la hipérbole y los paralelismos.

Con Isabel de Braganza surge la idea de la asociación de la crueldad de un destino compartido por ambos esposos, uno recluido en Valençay y la otra huida al Brasil por causa de los designios del malvado Napoleón, ${ }^{18}$ así como se inicia la construcción de la imagen de la reina doméstica. ${ }^{19}$ Isabel de Bra-

13 SALVADOR, José del, 1815. CALVO, Antonio, 2010, p. 21: "se publicaron a partir de 1808 varias obras con la intención de fomentar el mito del príncipe perseguido por Godoy y la reina, buscando legitimar la Conspiración del Escorial y el Motín de Aranjuez. Algunos de estos impresos incluyeron la muerte de la princesa María Antonia entre los crímenes del Príncipe de la Paz".

14 Gaceta de Madrid, 30 de marzo de 1819, p. 330-333; CALVO, Antonio, 2010, p. 31, señala que el papel de la Iglesia en los fastos eclipsó los de Academias y Sociedades, así como el de los Grandes de España, el orador del sermón indicaba que los nobles "jamás hicieron ninguna a otra soberana de España". El acto tuvo lugar el día 17 de marzo como si quisiesen conmemorar el día del Motín de Aranjuez.

15 DOMÉNECH, Albert, 2018, p. 224: “La impressió de les diverses relacions que expliquen aquestes cerimònies es popularitzaren sobretot a partir del s. XVI i arribaren a una gran propagació el s. XVIII. De fet, foren tant populars que aquests llibres o fulletons -en funció del pressupost dels comitents- s'han conservat en volums facticis que en recullen una bona collecció de zones geogràfiques i períodes concrets i limitats".

${ }^{16}$ Es el caso de la Oración fúnebre de ESTEVE DE SAN MIGUEL, Joaquín, 1829, publicada en Valencia por la imprenta de Benito Monfort, y en Madrid por la de Leonardo Núñez.

17 RELACIÓN, 1819, p. 8-9.

18 RELACIÓN, 1819

19 El modelo de la reina doméstica, más cercano al modelo femenino que propugnaban los reformistas ilustrados queda perfectamente reflejado en la obra que vio la luz en el Siglo de las Luces. CALVO, Antonio, 2006 y 2007, p. 33. 
ganza, como modelo virtuoso, era una Esther ante Asuero, y se la representa como enemiga de la ostentación, ${ }^{20}$ llegando a ofrecer sus alhajas para financiar la expedición que se dirigía a pacificar América. ${ }^{21}$ Así, la construcción del modelo de reina doméstica y su papel simbólico asociado a las virtudes que la reina debía poseer como modelo social, que se venían estableciendo desde finales del XVIII, cobra especial significado durante el reinado de Fernando VII. No obstante, esta imagen de la reina "virtuosa" quedaba siempre relegada a su papel como reverso de la figura del rey, atravesada por la construcción de la propia imagen del monarca como el rey deseado y víctima de las perfidias del enemigo francés, Napoleón, y de la traición de sus padres. Este destino cruel del rey víctima de la traición será un discurso que se acrecentará a partir de 1823, tras su segunda restauración en el trono. Los levantamientos liberales de 1817, 1819 y 1820 y el Trienio Liberal (1820-1823), junto a su cautiverio en el Puerto de Santa María en Cádiz, servirán de correlato a la fabricación del rey como insignia de los designios del pueblo español, que convertido en súbdito había luchado por su monarca durante la guerra de la Independencia. 22 Todos estos elementos, de una u otra manera, estarán presentes en los textos de las oraciones fúnebres y en las imágenes alegóricas que los distintos monumentos y catafalcos fúnebres, que se levantaron en distintas ciudades españolas, proyectaron en honor de la ahora reina fallecida.

Las honras fúnebres de María Josefa Amalia se celebraron el 27 y 28 de julio de 1829, si bien a los dos meses la prensa oficial se hacía eco del anuncio del nuevo enlace de Fernando VII con María Cristina de Nápoles; pues urgía un heredero para la corona, "fracasados" sus dos matrimonios anteriores. No es casualidad, pues, que la urgencia por asegurar la línea dinástica y la sucesión sea uno de los aspectos que con más énfasis se recogerá en las distintas oraciones fúnebres.

Entre las oraciones que se proclamaron en honor a la reina fallecida destaca el Elogio fúnebre que celebró la Real e Ilustre Congregación del santísimo Cristo de la Obediencia, en la Real y Patriarcal Iglesia de Nuestra Señora del Buen Suceso, ${ }^{23}$ que fue leído por el consultor de cámara del infante Sebastián, fray Ramón García de los Santos. En este Elogio se hacía una clara utilización, en una situación política complicada para una monarquía cuya imagen estaba profundamente deteriorada, del mito del deseado:

\begin{abstract}
¿Por qué llora este generoso pueblo? Si el cielo le permitió días de congoja y de susto, ¿no le ha consolado á proporción de sus desgracias? Si acaecimientos políticos, acaso singulares en la Crónica de las naciones, le llenaron de tristeza; si una conducta desconocida en la civilización moderna; apenas usada entre bárbaros, le dejó en una orfandad espantosa; si arrancó del seno de sus vasallos al mas digno de todos los Reyes, y le tuvo en cautiverio devorando pesares y volviendo continuamente los ojos á sus amados españoles que suspiraban por él como por su legítimo dueño; si una guerra desastrosa, en fin, le hizo sentir todo el peso de la desgracia ¿no le ha recompensado la Providencia tantos males con multiplicados bienes capaces de hacer olvidar aquellos días funestos? No tiene duda. El cielo nos hizo sentar á la sombra de la paz, y empezamos á coger sus dulces frutos. El Monarca deseado vino ya, y juntamente con él vinieron la satisfacción y el placer. $^{24}$
\end{abstract}

El rey es Asuero para una nueva Ester: un paralelismo que ya había sido utilizado en el caso de sus esposas anteriores y que es común al resto de los elogios que se leyeron en honor de María Josefa Amalia, de la que se ensalza especialmente su piedad y devoción "como dechado de una verdadera cristiana":

heredera de la sangre más noble y mas pura que jamás corrió por reales venas, ella realza todos estos timbres por su virtud. Prudente como Isabel la Católica, es pacífica como Margarita de Escocia, y admirable como Isabel de Hungría. ${ }^{25}$

Las alusiones a una de las obligaciones más significativas de las reinas, la maternidad, es eludida proclamándola madre de los españoles: "el trono la admiró sabia y prudente; nuestro Soberano tenía en ella una esposa amante y fiel, y la España la celebraba como una madre, conforme á las leyes del amor". Estos mismos argumentos se reiteran en la Oración Fúnebre que en las solemnes y Reales Honras celebradas de orden de S. M. el Se-

\footnotetext{
20 ARBIZU Y ECHEVERRIA, Xavier María de, 1819, p. 80 y 330.

21 GONZÁLEZ, Juan, 1819, p. 18. En todas estas descripciones observamos la imagen paradigmática de la reina fuerte que cede sus alhajas como Isabel I, y de la reina sabia, como Isabel de Farnesio o Bárbara de Braganza.

22 ALBA, Ester, 2016, p. 201-220.

23 GARCÍA DE LOS SANTOS, Ramón, 1829.

24 GARCÍA DE LOS SANTOS, Ramón, 1829, p. 5.

25 GARCÍA DE LOS SANTOS, Ramón, 1829, p. 8.
} 


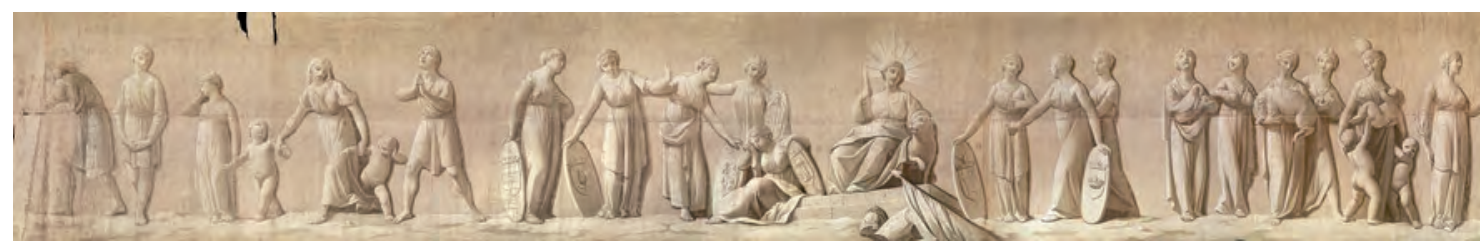

Fig. 1 bis. Zacarías González Velázquez, Friso del Cenotafio de Isabel de Braganza, 1819. Museo Cerralbo (005599).

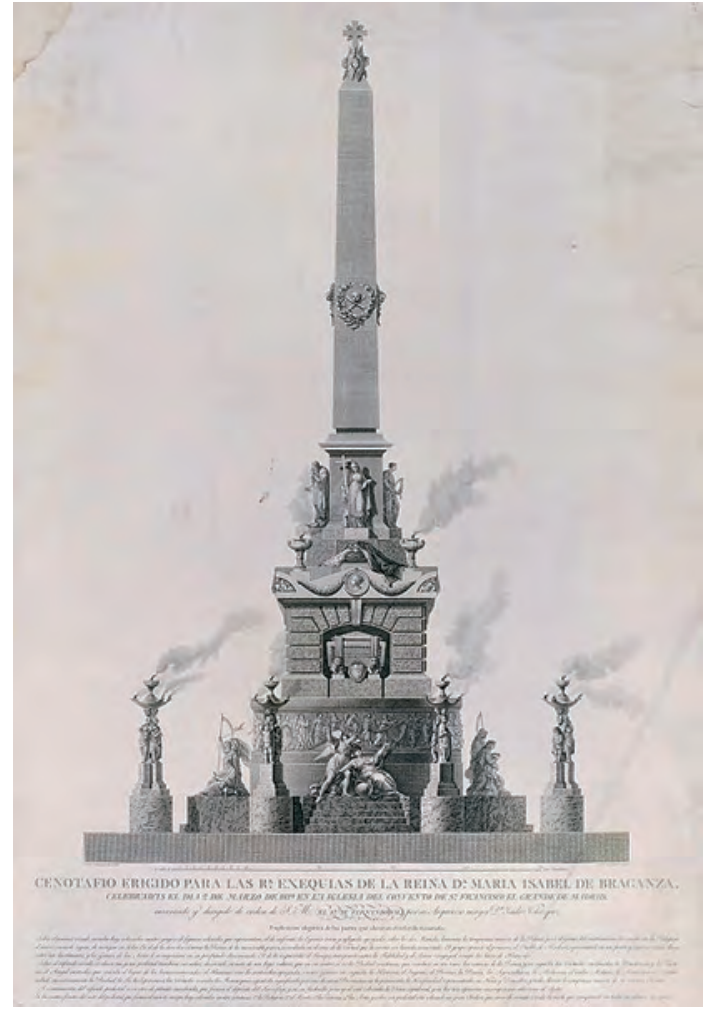

Fig. 1. Isidro González Velázquez inv. y dibo - Francisco Jordan le grabó. Cenotafio erigido para las reales exequias de la Reina María Isabel de Braganza, celebradas el dia 2 de marzo en la iglesia del convento de San Francisco el Grande de Madrid. Cobre, talla dulce. 770 x 542 mm., 1819. Biblioteca digital memoria de Madrid.

ñor $D$. Fernando $V I I,{ }^{26}$ en la que se pone el acento en su papel como "reina cristiana".

En la iglesia del Real convento de la iglesia de San Francisco el Grande de Madrid, se levantó el Cenotafio para las honras fúnebres de la Reina María Amalia de Sajonia, que se describe en la Descripción del cenotafio erigido para las reales exequias de la

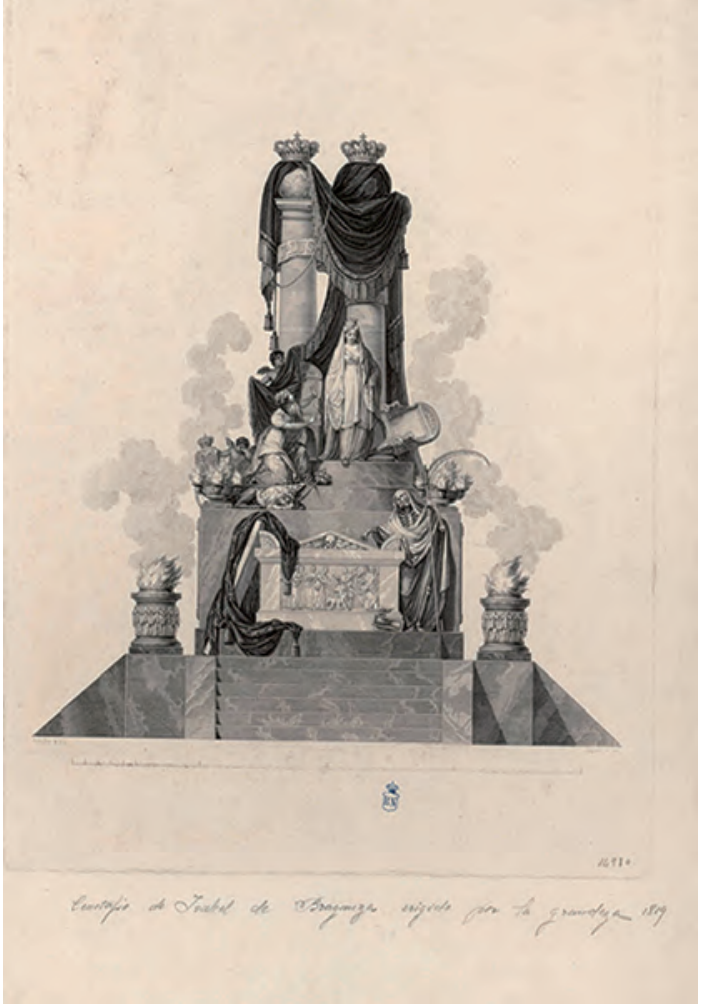

Fig. 2. Alejandro Blanco y Asensio lo grabó, José Ribelles lo dibujó. Relación de las exequias que celebran los Grandes de España en la Iglesia de San Isidro El Real de esta Corte el día 17 de marzo del presente año de 1819 en sufragio de la Reina María Isabel Francisca de Braganza. Cobre, talla dulce, 1819. Biblioteca Nacional de España.

Reina Nuestra Señora D.a. María Josefa Amalia de Sajonia, celebrada el 28 de julio de $1829 .{ }^{27}$ El diseño en perspectiva del cenotafio y decoración del monumento son conocidos gracias a la litografía de Vicente Camarón, pintor, grabador y litógrafo natural de Madrid e hijo del valenciano Juan José Camarón Melià, pintor de cámara de Fernando VII, sobre el diseño de Isidro González Velázquez, quien

${ }^{26}$ RODRÍGUEZ DE CÁMARA, Eduardo, 1829.

27 DESCRIPCIÓN, 1829a. El monumento alcanzó un coste total de 681.476 reales. Respecto al autor de la litografía, esta fue realizada por Vicente Camarón, cobrando por la misma 9.000 reales, y alcanzando la estampación de esta en los talleres del Real Establecimiento la cantidad de 6.000 reales. 
lo realizó por encargo del monarca. Para honrar la muerte de la reina, el monarca ordenó erigir un catafalco fúnebre en la iglesia de San Francisco el Grande de Madrid; inventado por el arquitecto mayor Isidro González Velázquez, similar al que había realizado anteriormente para la muerte de la segunda esposa de Fernando VII, Isabel de Braganza (Fig. 1 y 1 bis), una combinación de templo clásico y obelisco inmerso en un fondo escenográfico que simulaba un panteón real. ${ }^{28}$ Aunque guarda una relación estética mayor con el monumento que los "grandes de España" levantaron en honor a la reina en la iglesia de San Isidro del Real el 17 de marzo de 1819 que se conoce a través de una calcografía de Alejandro Blanco y Asensio sobre un dibujo de José Ribelles (Fig. 2). Se trataba de un catafalco fúnebre de gran esencia romántica y una gran carga alegórica en la que el sentimentalismo ante la tragedia de la pérdida y las alusiones a la muerte arrinconan las estereotipadas iconografías de antaño. ${ }^{29}$

En las exequias de María Josefa Amalia de Sajonia se aprecia un aumento de los grabados que acompañan las relaciones u oraciones. A menudo, estos se vendían por separado y se anunciaban en la prensa; pero lo más importante es que estos grabados eran realizados para ser comercializados, aprovechando la expectación de la ceremonia y el golpe emocional del duelo, a partir del proyecto realizado por el tracista con la intención de ser vendidos junto a los libros. ${ }^{30}$ Ello se debe en parte a la consolidación de la técnica de la litografía, más rápida y económica. Este cambio lo apreciamos en los grabados que se han conservado de las exequias de María Josefa Amalia de Sajonia, en las que hay una predilección por el uso de la litografía, ${ }^{31}$ lo que se tradujo en grabados de tamaño menor, debido a las medidas utilizadas en las piedras litográficas.
Este grabado litográfico (Fig. 3) muestra una vista frontal del monumento, de estilo clásico, y la decoración de la iglesia. El monumento estaba compuesto por un templete levantado sobre columnas dóricas y frontón, bajo el que se guarda el catafalco. Sobre este, rematado por cuatro monolitos, aparece la figura de la Religión. A su vez, un tercer piso se adorna con un tronco de columna estriada que se halla rematado por el grupo escultórico de la Reina. Cuatro grandes hachones flanquean el monumento, en cuyo frente se ha colocado la figura de las Artes, de quien la Reina fue protectora y benefactora. En la realización del cenotafio y decoración de San Francisco El Grande, en el que destaca la utilización de obeliscos junto a un lenguaje clásico y símbolos románticos asociados a la muerte, intervinieron numerosos artistas de la época, dirigidos por el arquitecto mayor Isidro González Velázquez; y entre los pintores que participaron en la decoración, Ossorio menciona que la realización de la pintura, "imitando un relieve" de uno de los medallones del catafalco de la reina, fue ejecutada por el pintor alicantino José Aparicio e Inglada. También participaron otros pintores como Juan Gálvez, González Velázquez, Angel Tadey, Juan de Ribera y Juan Archelerguez, además del dorador Ramón Lleget, y entre los escultores cabe citar a Pedro Hermoso que llevó a cabo algunos bajorrelieves y las esculturas de las cuatro Virtudes Cardinales; Francisco Elías realizó el grupo escultórico de la Reina y la restauración de algunas de las esculturas y relieves anteriores que habían servido para el monumento de Isabel de Braganza -esta reutilización de estructuras anteriores era algo habitual-; José Tomás esculpió las de España y Sajonia; Manuel de Agreda, las figuras de León y Cantabria; Ramón Barba, las figuras de las Ciencias y las Artes, y Valeriano Salvatierra, las estatuas de Ara-

28 GONZÁLEZ, Pablo; ALBA, Ester, 2013, p. 50-64. Los monumentos levantados en las exequias a Isabel de Braganza son considerados los primeros en los que se produce un cambio en el lenguaje artístico, en el que el lenguaje barroco cede al romanticismo y a la representación de la muerte. El seguimiento de la estética planteada en las exequias romanas ha sido una constante en la estética de las arquitecturas efímeras españolas, especialmente relacionadas con los aparatos que en edad Moderna se levantaron en Santiago de los españoles en Roma. FAGIOLO, Maurizio, 2005.

29 Gaceta de Madrid, 91 (17 de marzo de 1819), p. 370-371.

30 DOMÈNECH, Albert, 2018, p. 226-227, excepto algunos que se realizarían con carácter posterior. Este autor indica que ello hace que no podamos conocer exactamente con exactitud la obra real levantada pues no son fieles a la realidad, pecan de cierta idealización y faltan elementos de contextualización como el marco del espacio arquitectónico en el que se construye, las luminarias que resaltaban efectos y virtudes de la construcción, y la materialidad de las arquitecturas: "La urgència en la construcció dels túmuls, que eren unes estructures de gran complexitat amb unes dimensions que oscil.laven entre els 10 i els 20 metres van provocar que els túmuls fossin construïts amb materials de molt baixa qualitat, dissimulats mitjançant artificis òptics. Els materials podien ser fusta, cartró, teles, estuc, canyes, estopa, cals, guix, miralls, lluminària, garlandes florals, escuts, banderes, quadres, etc., tot pintat amb simulacions de marbres, bronze i daurats que permetien fer dissenys originals i fantasiosos, i que creaven una escenografia impactant. Les diverses fonts parlen precisament de la tasca que ocupava els diversos artesans com ara fusters, dauradors, guixaires, etc., i artistes com arquitectes, tracistes, escultors i pintors".

31 DOMÈNECH, Albert, 2018, p. 231: "de la tècnica, ja que les pedres litogràfiques que són la base del gravat eren més petites a l'inici de la implantació d'aquest revolucionari sistema d'impressió. Només les darreres exèquies de Ferran VII, sense aconseguir-ho, intenten tenir les dimensions dels gravats del s. XVIII". 


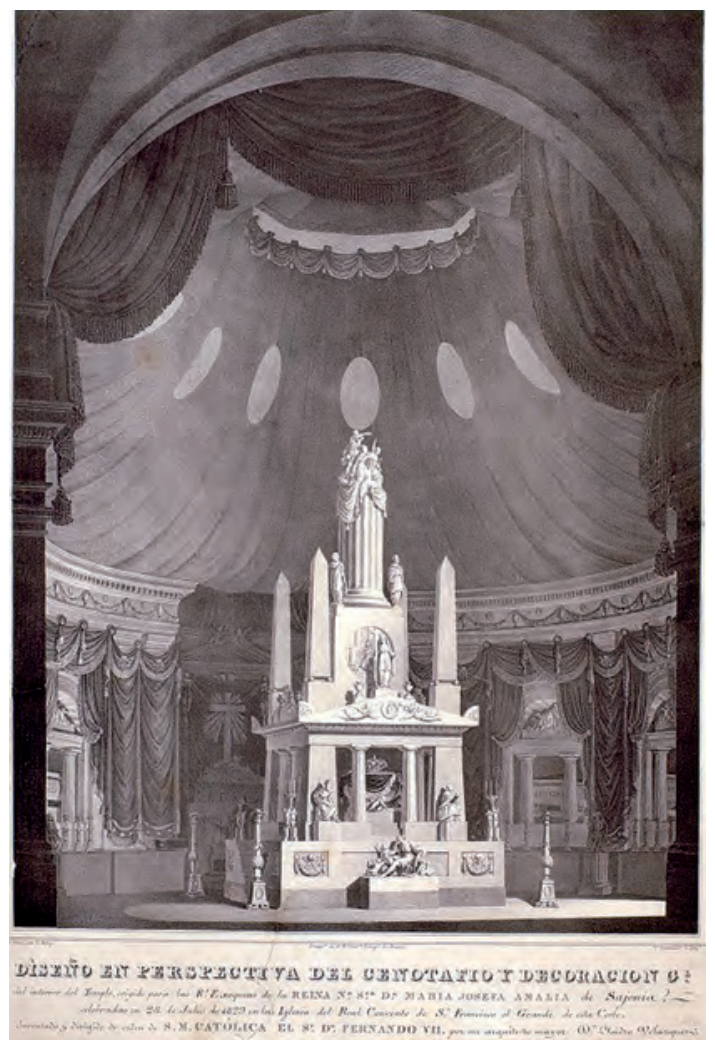

Fig. 3. Isidro González Velázquez lo dibujó. - Estampado en el Rl. Estabt ${ }^{\circ}$. Litogro. de Madrid, Vicente Camarón y Meliá. lo Litogo. I Diseño en perspectiva del cenotafio y decoracion GL. I del interior del Templo, erigido para las R.s Exequias de la Reina N.a Sra D.a María Josefa Amalia de Sajonia, / celebradas en 28. de Julio de1829 en la Iglesia del Real Convento de S.n Francisco el Grande de esta Corte. / Inventado y dirigido de orden de S. M. Católica EL S.r D.n. Fernando VII. por su arquitecto mayor Dn. Isidro Velazquez, 1829. Litografía, 553 x 380 mm. Biblioteca Digital memoria de Madrid.

gón y Castilla. Asimismo, el monumento se acompañó de la estatua de la Religión, obra del falleci- do escultor de cámara José Ginés, la cual había figurado en el catafalco de 1819 para la reina Isabel de Braganza. ${ }^{32}$

Uno de los elementos más significativos de estas exequias fue el aumento de las relaciones que se imprimieron, algo que fue común en las exequias de Fernando VII en 1833, especialmente en Barcelona y en Valencia. Fenómeno que hemos de relacionar con la difusión de la nueva técnica litográfica, que permitió que las diversas instituciones y organizaciones imprimiesen sus túmulos fúnebres. ${ }^{33}$ Igualmente destaca el hecho de la que todo el conjunto de relaciones fuese escrito en castellano, así como las placas e inscripciones que acompañaban a los monumentos. En el siglo XVIII, la lengua utilizada de manera sistemática había sido el latín hasta 1816, cuando se incorpora el castellano, aún alternando con el latín, que se impone de manera definitiva en los escritos que en papel o en lápidas acompañaron a las exequias de María Josefa Amalia (1829) y Fernando VII (1833). ${ }^{34}$ Una muestra evidente de interés por llegar al pueblo, comercializar y difundir el mensaje.

Los elogios fúnebres en la ciudad de Barcelona fueron muy abundantes y sonados, ante el impacto de una nueva muerte regia y el problema que suponía la edad avanzada del monarca y la ausencia de descendencia que legitimase la continuidad monárquica. ${ }^{35}$ Uno de los más destacados fue el Elogio fúnebre que en las exequias de la Reina y Señora doña Josefa Amalia de Sajonia celebradas por el Real Acuerdo de la Audiencia de Cataluña en la parroquial Iglesia de Sta. María del Mar el día 3 de junio de 1829, a cargo de fray Martín Estaper, religioso jesuita. ${ }^{36}$ Es significativo el papel de los jesuitas en los funerales de la reina, pues por un lado hemos de recortar la restitución de la orden por Fernando VII tras la expulsión de Carlos III, y que

32 TORRES GONZÁLEZ, Begoña, 2001, cat. 100, p. 345, en el que se recoge la bibliografía anterior. El complejo programa iconográfico venía a redundar en la construcción de la reina "virtuosa" utilizando el tradicional recurso de las virtudes cardinales, propias de toda soberana, así como su papel protector y benefactor de las artes y protectora de la religión como "reina católica".

33 DOMÈNECH, Albert, 2018, p. 231 relaciona, además, este hecho con la presencia de los monarcas en Cataluña durante sus visitas de 1828, algo que podemos trasladar igualmente a Valencia. ALBA, Ester, 2016. Por otro lado, en la Hispanic Society. New York, se conservan, además, la ORACIÓN fúnebre que en las exequias solemnes celebradas en memoria de su nada reyna y señora, Doña María Josefa Amalia [...], el domingo 5 de julio de 1829 en la Iglesia del Convento Casa Grande de Mercedarios calzados de esta ciudad. Sevilla, Impreso por Hidalgo y Cia, a expensas de la Real Archicofradia, y la Oración fúnebre celebrada en la catedral de Cuenca por AMAT, Cristóbal 1829. Esta última es muy interesante pues introduce aspectos políticos de interés relacionados con los cercanos acontecimientos de la sublevación catalana dels Malcontents: "iAh! Y qué hubiera sido de la suerte de nuestra España, en especial de algunas de sus Provincias, si el Ángel de la Paz no hubiera inspirado á nuestro afligido Monarca aquella resolución heroica que hará época en los fastos de los siglos1 En ella no sé qué admirar, ó alabar con más encomio, si la magnanimidad de nuestro venerado Rey, ó las virtudes ó prendas singulares de nuestra adorada Reyna".

34 DOMÈNECH, Albert, 2018, p. 233.

35 Destaca el texto de ARRAMBIDE, Juan Manuel, 1829: Hispanic Society New York (PQ 653/A7892E).

36 ESTAPER, Martín, 1829. 
fue la principal impulsora de la devoción al Sagrado Corazón de Jesús, tan venerado por la reina. En este Elogio se hacía eco del funesto destino que parecía atacar a la monarquía española:

Qué es esto? ¿Aun el mas brillante Trono no puede eximirse de verse algún dia trocado en un lóbrego atahud? ¿La juventud mas lozana no puede estar à cubierto de los asaltos de la muerte? ¿Los cetros mas fuertes han de romperse, y las flores mas esquisitas y odoríferas han de marchitarse y secarse para siempre? ¿Los enlaces mas estrechos y mas sagradamente formados han de desatarse para no volverse a unir jamás? ¿Las fiestas y regocijos, que la magnificencia de los Reyes exige, y les consagra la fidelidad y gratitud de los pueblos, han de ser turbados en la hora menos pensada por el luto que la muerte esparce sobre ellos? ¡Ay! Ese suntuoso y lúgubre aparato, que hiere nuestros ojos y melancoliza nuestros corazones; esa pálida cera que está ardiendo, y no despide mas luz que la necesaria para descubrirnos objetos de dolor. ${ }^{37}$

En estos elogios se recogía la fisonomía del cenotafio levantado en el crucero de la iglesia de Santa María del Mar, de Barcelona, en el que el catafalco se describía como un "fúnebre cenotafio, que contemplamos en medio de este magestuoso Templo á manera de trono donde sentada la muerte, parece nos está insultando a todos, y se vanagloria de ver a sus pies preciosos Reales despojos; esos cánticos melancólicos que penetran nuestros oídos; esas negras bayetas, que cubren las paredes de este grandioso Santuario; ese luto general, que á todos nos comprende; todo nos presenta un testimonio, el mas auténtico de los triunfos de la muerte, y del poder absoluto que ejerce sobre todos los vivientes sin excepción de clases, de edad, de sexo, ni de jerarquía". ${ }^{38}$ Descripción que se acompañaba de un grabado litográfico (Fig. 4), sobre dibujo de Buenaventura Planella Conxello ${ }^{39}$ (Barcelona, 1772-1844), profesor de la Escuela de la Llotja y pintor escenógrafo especializado en teatros.

Las exequias celebradas en Barcelona correspondían al "Real Acuerdo en representación de todo el Principado de Cataluña", en ellas, y dado el carácter conservador y reaccionario del clero catalán, se hacía una semblanza de la reina adecuada a su papel como defensora del catolicismo, ejemplo de virtudes y fiel esposa y se la nombraba "hermosura de virtudes hasta el último período de su vida":

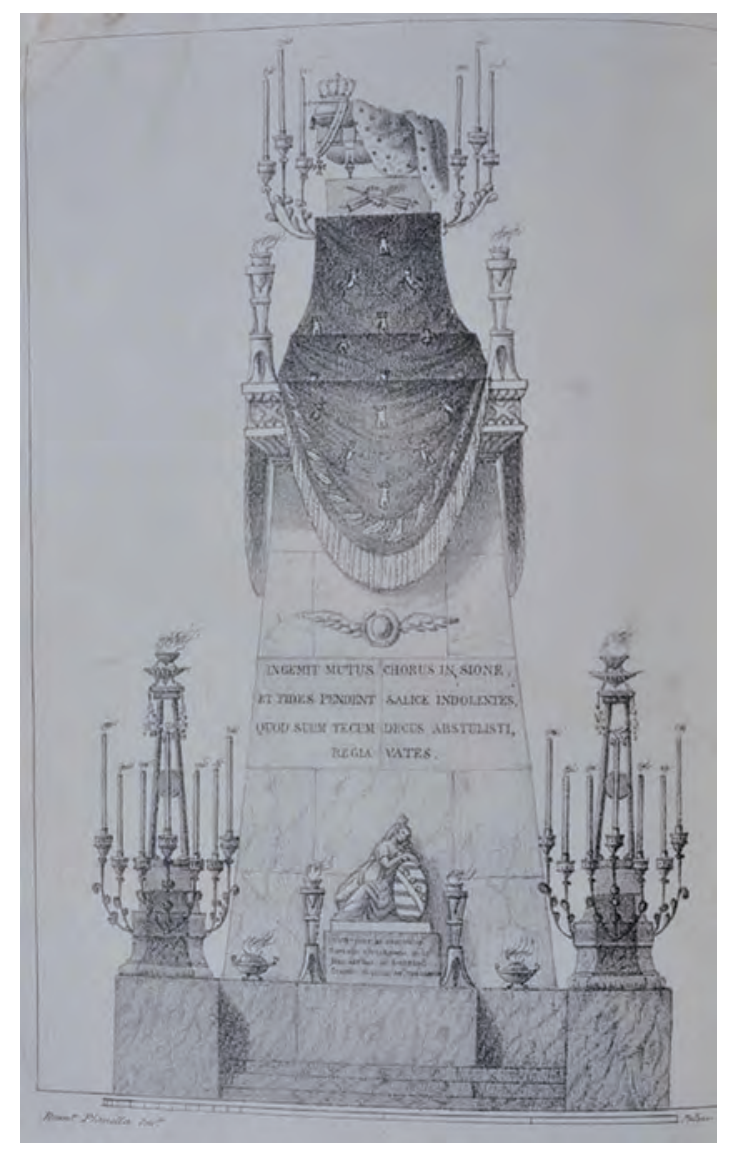

Fig. 4. Buenaventura Planella Conxello lo dibujó. ESTAPER, Martín. Elogio fúnebre que en las exequias de la Reina y Señora Doña María Josefa Amalia de Sajonia (...). Barcelona: Imprenta de Joan Francesc Piferrer, 1829.

¡Ah! Bien lo sabéis, oyentes amados; no hubo jamás otra muerte mas digna de las lágrimas que vertemos: es la muerte de aquella Reina Augusta y respetable, cuyas virtudes edificaban la Corte, santificaban el Reino, hacían la gloria de la Religion, formaban la felicidad de nuestro Soberano, y arrebataban la admiración y estima de los pueblos: es la muerte de aquella Princesa virtuosa, superior á la adversidad, de la que tuvo que probar bastante amargos tragos, superior á la misma muerte, de la que soportó con la mas heroica resignación todos los horrores. ${ }^{40}$

Además, se ofrecía una semblanza de la reina que se ajustaba a la perfección a su discurrir en la Corte a lo largo de su vida, poco participativa en la actividad cortesana:

\footnotetext{
37 ESTAPER, Martín, 1829, p. 3-4.

38 ESTAPER, Martín, 1829, p. 4.

${ }^{39}$ DESCRIPCIÓN, 1829b.

40 ESTAPER, Martín, 1829, p. 5.
} 
Contempladla pues ya en la Corte de Madrid, mirad ya en Josefa Amalia la Reina de España; mas yo dudo, que por el método de vida que emprende, sepáis reconocerla por nuestra Soberana. Retiro, rezo, recogimiento, soledad, silencio, devoción, oración, en una palabra todo lo que parecía menos propio para su edad de 15 años escasos y para su elevado rango, venía à serlo para su metódica virtud, tan ejercitada, que casi formaba su carácter (...) Agradar á su esposo era su principal ocupación y su único placer. ${ }^{41}$

En esta oración, no faltaron las alusiones a las "traiciones liberales" y la defensa de la legitimidad de la soberanía encarnada en el monarca absoluto, ungido por la gracia divina:

La Divina providencia (...) no permite la persecución del justo, sino para acrisolar mas su virtud, y poner á prueba; (...) la humana prudencia, restituye la libertad á un Rey violentado; y mientras que tantos Jeroboanes, que se atrevieron á levantar sus sacrílegas manos sobre el ungido del Señor, tienen que huirse despavoridos del Reino; vuelve este á entrar en el pleno ejercicio de los legítimos derechos de su Soberanía. Virtuosa Esther, el tiempo de prueba ya pasó; vuelve á rayar otra vez el de la gloria: desde la sombra del Santuario, donde te hayas recogida sin más compañía que la de la virtud, un Rey que te ama, te convida á unir tu destino con el suyo. Sube pues, Señores Fernando con magestad al trono, y á su lado va á participar Amalia de la gloria de los triunfos de la legitimidad. ${ }^{42}$

Este discurso en el que se hacía eco del destino trágico del monarca y de su carácter como príncipe amado por el pueblo, recuperando la idea del mito del "Deseado" -que se había construido durante la guerra de la Independencia, mientras Fernando VII permanecía ausente en cautiverio, como resultado de la traición-, se incardinaba con las traiciones liberales. Un claro ejemplo de la diseminación de esta idea se encuentra en los textos poéticos de Juan Miguel de Arrambide, en Madrid, en los que se dolía de este infausto destino:

¿Cuándo será que la potente diestra, / De vos igran Rey! La inmensa pesadumbre / De pesares sin cuento y de infortunios / Destierre por jamás, y en vuestro pecho / Fije la dulce y apacible calma / Que en el bien nace y la ventura aumenta? / ¿Y cuándo en el regazo cariñoso / De la divina paz y de la gloria, / La regia frente de laurel ornada / Ostentaría jó Príncipe adorado! / El digno galardón de tus virtudes? ${ }^{43}$
Por otro lado, el Elogio fúnebre leído en el convento de San Francisco de Asís de Barcelona, ${ }^{44}$ se hacía eco, de nuevo, de las virtudes tradicionales que habían de cumplir las reinas y se revitalizaba el mito del infortunado Fernando y se le comparaba con las más virtuosas reinas, especialmente con María Amalia de Sajonia, esposa de Carlos III:

"Murió y con su muerte prematura perdió nuestro Monarca una Esposa sumamente acreedora á su Real aprecio, la Religión un sostén muy poderoso, las artes una decidida protectora, los pobres y desvalidos una madre compasiva", "Su estatura y modales quizá no os prometerán una valerosa Judith, una esforzada Jael, una Artemisa emprendedora, ó una Semiramis conquistadora; pero que importa, si María Josefa no viene á cortar cabezas, ni á conquistar provincias, sino corazones. Vosotros no pensaréis ver una Aspasia mujer de Pericles, ó una Isabel la Católica capaz de manejar las riendas del gobierno, como las manejó aquella en la Grecia, está en España, pero que importa si María Josefa no viene a gobernar. No reconoceréis en ella el aliento para defender una plaza, como Doña Urraca, pero que importa si MARía JOSEFA no viene á empuñar la espada ni á defender plazas. No, Josefa no viene á hacer un papel brillante entre los estadistas ó diplomáticos; no á entrometerse en asuntos políticos; no á dar pábulo al vocinglero clarín de la fama, para que la publique profunda política, valiente heroína; señora de gusto: viene á ser modelo de reinas, dechado de virtudes; á presentar una copia de otra María Amalia de Sajonia, á dar pruebas de que sus pies siguen los vestigios de las Isabelas de Hungría, de las de Portugal, de las Margaritas de Escocia. Así es, que España traslucirá luego los subidos quilates de su virtud por entre los celages de su humildad, de su modestia y disimulo, y en breve se grangeará la mayor nombradía, y sus obras la harán famosísima en España, como á Judith en Israel" . 45

Los contenidos asociados a la muerte, tanto en la decoración de los túmulos como en los textos literarios fueron un elemento frecuente. Si bien el paralelismo histórico con las reinas del pasado fue un elemento recurrente, así como los contenidos políticos en defensa de la monarquía absolutista de Fernando VII, otros poemas tuvieron un componente lírico más cercano a la poesía bucólica. Así Lorenzo Arrazola, en Valladolid, cerraba su Canto lúgubre con una égloga o diálogo lúgubre entre el pastor de Arcadia, Dorilo, y Celenio, pastor del Henares:

\footnotetext{
${ }^{41}$ ESTAPER, Martín, 1829, p. 15.

42 ESTAPER, Martín, 1829, p. 21-22.

${ }^{43}$ ARRAMBIDE, Juan Manuel, 1829.

${ }^{44}$ CILLA, Vicente de, 1829, p. 28.

${ }^{45}$ CILLA, Vicente de, 1829, p. 10.
} 


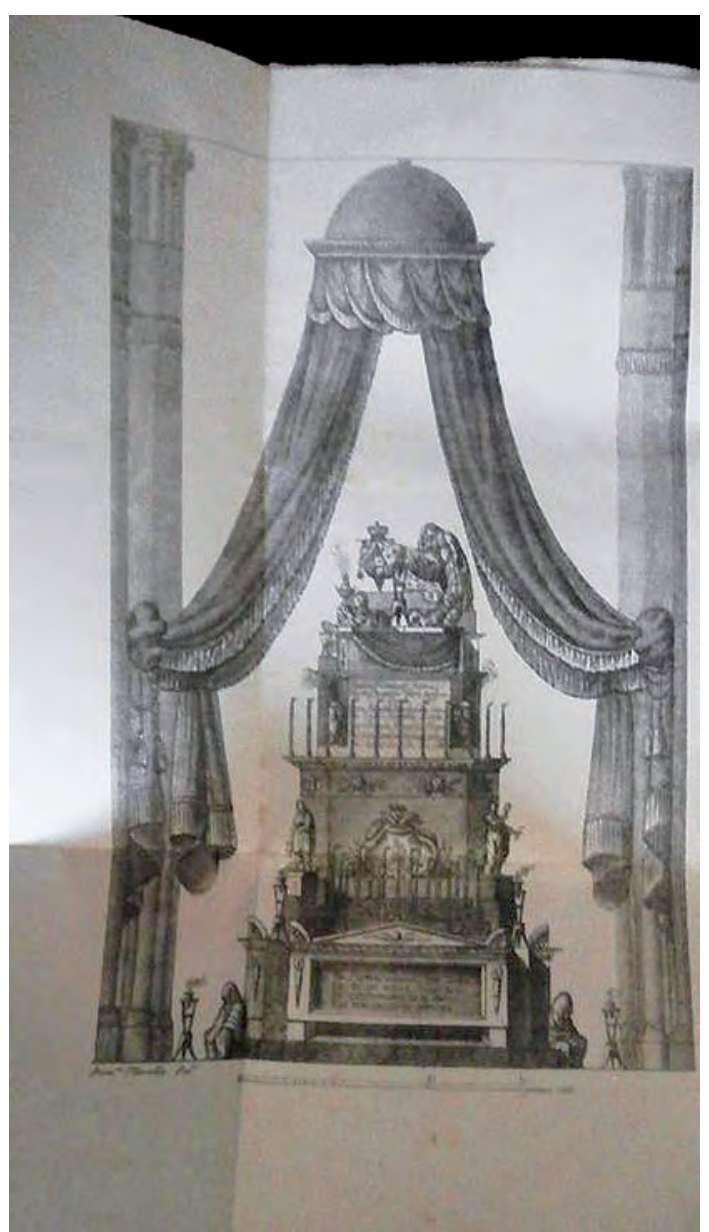

Fig. 5. Sucinta relacion de las honres fúnebres que a su augusta soberana. Sra. Doña María Josefa Amalia Reyna de Espa$\tilde{n} a$ (...). Barcelona: Imprenta de Joan Francesc Piferrer, 1829.

“Dorilo: Ya el Sol sus rojas luces / recoje á toda prisa / y ya van ¡ay! Las sombras / saliendo de las selvas / Adiós césped amado / Adiós olmos, hiedra/ Adiós cara Mirtila: / Esta es la vez postrera / Que hoy obre tu sepulcro/ Siembro flores...". El canto comenzaba con alusiones clásicas y en las que, de nuevo, con un lenguaje diferente, recogía las virtudes de la reina: "Que murió Amalia, y en su muerte es poco / que el mundo llore / Llore el Parnaso, pues perdió una Musa; / Llore la Hesperia, la Sajonia Ilore; / y el Pueblo, el Clero, la Milicia, y todos / sientan acordes!... Llevas el nombre / Pero la tumba de la casta Amalia / Los silenciosos sepulcros, los bronces, / las enlutadas religiosas urnas, / ¿Qué es lo que esconde? / Virtudes, gracias, juveniles años, / Ciencia sin fausto, peregrinas dotes. / Bondad, dulzura, y el candor más puro, / Tímido y noble". ${ }^{46}$

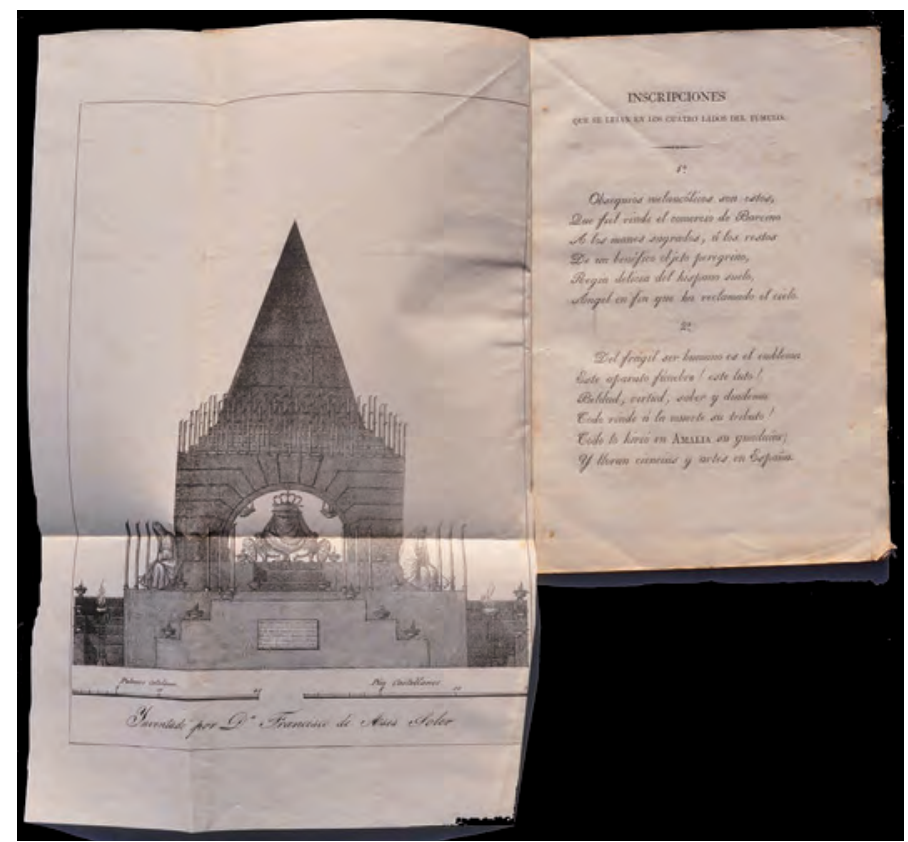

Fig. 6. Francisco de Asís Soler lo dibujó. Cenotafio erigido por la Rl Junta de comercio en las exequias celebradas para la Reina $N^{a} S^{a} D^{a}$ Maria Josefa Amalia de Sajonia en la Iglesia de los PP. Mercenarios de esta ciudad el dia 16 de Junio de 1829. DE LOS DOLORES, Manel. Oración fúnebre que en las ecsequias funerales celebradas por disposición de la Real Junta de Comercio de Cataluña (...) en sufragio de la Señora Da María Josefa Amalia (...). Barcelona, Vídua d'Agustí Roca. Litografía: 320 x 220 mm., 1829.

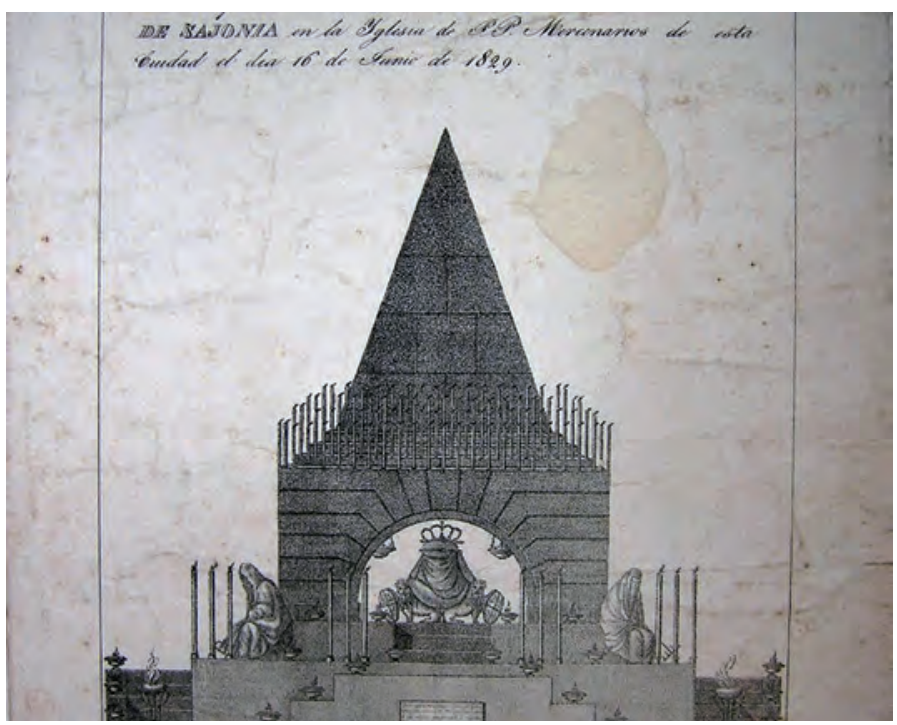

Fig. 6 bis. Detalle. 
Estas expresiones poéticas fueron comunes en otras ciudades entre las que destacan las Poesías á la reina Doña Josefa Amalia, impresa en Zaragoza en 1829, los Sáficos á la Reina María Josefa Amalia, las Poesías lúgubres á la sensible muerte de la Reina de España, obra de Cayetano Puch y Portalés, En la temprana muerte de la Reina N.S. Doña Maria Josefa Amalia de Sajonia, de Manuel Ruiz Crespo, y el Canto fúnebre en la muerte de la reina de España doña Josefa Amalia de Sajonia compuesto para el día que celebra sus exequias la ciudad de Cádiz, de Esteban Picardo. ${ }^{47}$

En Barcelona se conservan otros dos grabados de túmulos funerarios asociados a textos impresos. Se trata del cenotafio inventado por el artista Francisco de Asís Soler para ceremonia que el 16 de junio de 1829 se celebraría en la iglesia de los PP. Mercedarios de Barcelona, ${ }^{48}$ y el grabado del túmulo que acompaña la Sucinta relación de las honras fúnebres, publicada en la imprenta de Joan Francesc Piferrer, en 1829. Este monumento (Fig. 5) destaca por seguir grosso modo el modelo de cenotafio que se levantó en Madrid y que seguía los modelos anteriores empleados en las exequias de Isabel de Braganza, en el que destaca la escenografía bajo un ampuloso dosel y la figura femenina doliente velada que llora sobre el simbólico sarcófago vacío adornado con la corona y la manta de armiño y las dos figuras veladas en símbolo de duelo en las esquinas de la arquitectura. Estas mismas imágenes románticas pueblan el monumento de la iglesia mercedaria (Fig. 6 y 6 bis), con idénticas figuras dolientes. No obstante, este sepulcro destaca por la innovación en su composición arquitectónica piramidal y su forma escalonada que recuerda las composiciones de los arquitectos utópicos Ledoux y Boullée inspirados en los mausoleos de la antigüedad romana. La utilización de arquitecturas inspiradas en elementos piramidales, obeliscos, etc., provenientes del antiguo Egipto o de Mesopotamia, comienzan a introducirse asociados a la estética funeraria y rompen con el clasismo purista de la academia ya desde los monumentos funerarios dedicados a Isabel de Braganza. Estas formas piramidales habían sido utilizadas con anterioridad en monumentos como los que se diseñan en 1820, en Madrid, para el cenotafio en memoria de las víctimas del Dos de Mayo (Fig. 7), y será un elemento recurrente en los túmulos funerarios que en honor de la reina se levantaron también en Valencia. Estos mismos elementos románticos: las figuras escultóricas veladas en asociación al duelo ante la muerte, las figuras dolientes y el obelisco culminando el túmulo, aparecen en el monumento que se levantó en la catedral de Palma de Mallorca, en el que destaca, además, el hecho de que la urna se apoye sobre dos bustos del rey y de la reina de manera simbólica (Fig. 8). ${ }^{49}$

Como en otras ciudades, en Valencia, tras recibir la noticia, las principales instituciones decidieron celebrar las exequias en honor de la reina fallecida, con funciones fúnebres y el alzamiento de monumentos, que como en los casos anteriores fueron encargados a los artistas más reputados de ese momento: Miguel Parra Abril, pintor honorario de la Corte, y Anselmo Alfonso, pintor especializado en escenografías. El primero ya había intervenido en las exequias reales de 1819, y el segundo intervendría en alguna de las decoraciones levantadas, meses después en honor de la futura reina, la princesa María Cristina, durante los festejos celebrados en su paso por Valencia. ${ }^{50}$

El 22 de mayo de 1829, el Ayuntamiento recibía la noticia a través de misiva real: "Habiéndose servido Nuestro Señor de pasar a mejor vida a la Reyna mi muy cara y amada Esposa (...) he resuelto con el dolor que me debe este tan sensible contratiempo avisaros de ello para que como tan buenos y leales vasallos cumpliendo con vuestra obligación dispongáis que en esa ciudad se hagan las honras, funerales y demostraciones que en semejantes casos se acostumbra". ${ }^{51}$ Se acordó señal de luto y se cerraron las puertas de las Casas consistoriales, y diversas instituciones, el propio Ayuntamiento, ${ }^{52}$ el Real Acuerdo de la Audiencia de Valencia, el Cuerpo de la Real Maestranza y la Universidad, celebraron las exequias en honor de la difunta reina María Josefa Amalia de Sajonia, levantando monumentos fúnebres para la ocasión. Estos monumentos se inscriben dentro de las coordenadas que marca el gusto existente en la época,

\footnotetext{
47 Hispanic Society, New York (94607092 H 557). Destacan igualmente las HONRAS, 1829 que se celebraron en el Real Monasterio de San Gerónimo Granada y las ESCEQUIAS, 1829 en la Catedral de Mallorca (Biblioteca de Patrimonio Nacional, IX/3484 y CAJ/FOLL4/235 (9).

48 DE LOS DOLORES, Manel, 1829.

49 ESCEQUIAS, 1829. Este libro se acompaña de la litografía del túmulo levantado en la Catedral.

50 CABRERA, Inés, 2013, p. 685-698.

${ }^{51}$ AHMV. Libro Capitular de 1829, fol. 127. ALBA, Ester, 2004, p. 408.

52 ELOGIO, 1829 y DESCRIPCION, 1829c.
} 


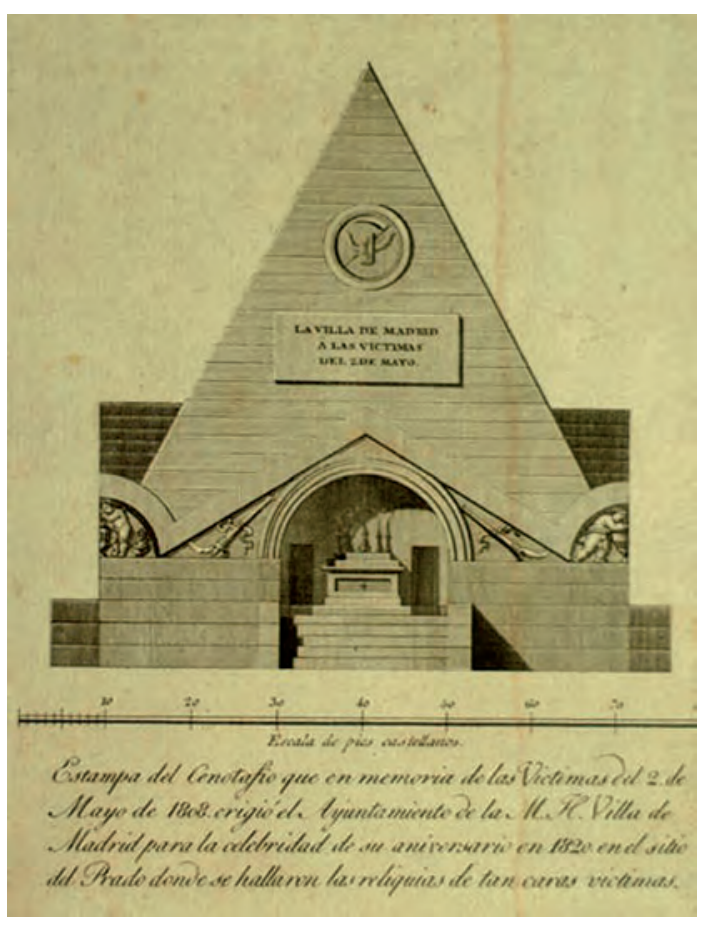

Fig. 7. Cenotafio en memoria de las víctimas del 2 de Mayo de 1808, erigido por el Ayuntamiento de Madrid en el sitio del Prado en 1820. Grabado, buril, 187 x $134 \mathrm{~mm}$. Biblioteca Digital memoria de Madrid.

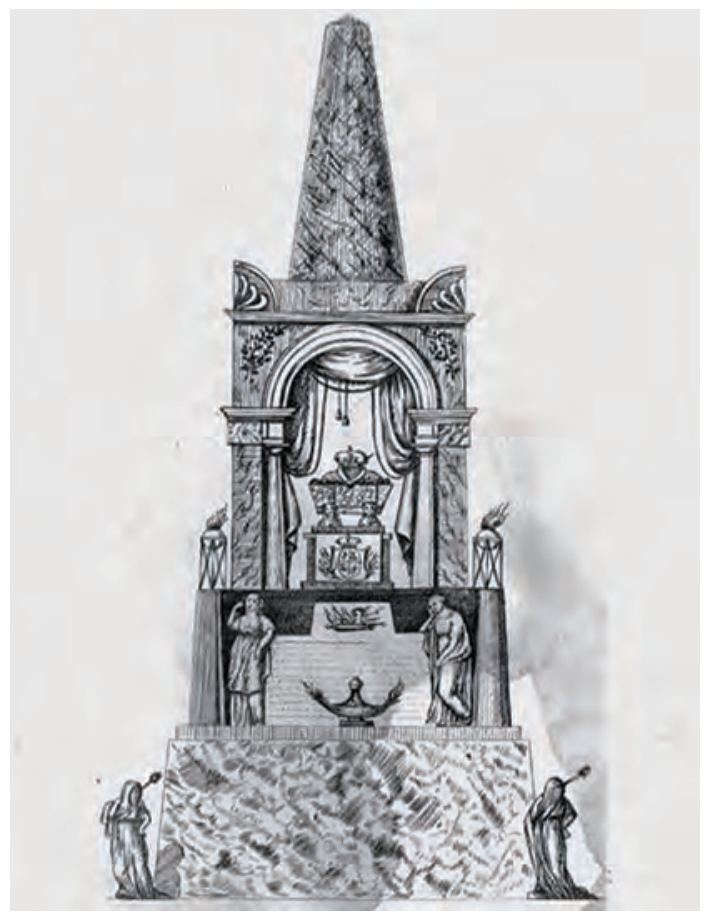

Fig. 8. Cenotafio en memoria de María Josefa Amalia de Sajonia en la Catedral de Palma de Mallorca. Escequias [sic] que la Muy Noble y Muy Leal ciudad y Reyno de Mallorca bizo en la Iglesia catedral de la isla el dia 17 de julio de 1829 a la Católica Magestad de la Reyna Nuestra Señora Doña María Josefa Amalia. Palma: Imprenta de Buenaventura Villalonga, Año de 1829. en el que el academicismo ilustrado va introduciendo algunos aspectos románticos, aunque perviven las estructuras clásicas, los obeliscos o estructuras piramidales, y los templos como elemento articulador de la maquinaria fúnebre.

La primera institución en organizar los actos diversos por el fallecimiento de la reina fue el Real Acuerdo de la Audiencia de Valencia, en la iglesia del Convento del Carmen de Valencia, el día 15 de junio de $1829 . .^{53}$ Como marcaba la tradición, junto a la función fúnebre, se decoró la iglesia con los habituales crespones negros, y se levantó un magnífico catafalco (Fig. 9). ${ }^{54}$ Dado el carácter efímero de estas decoraciones, conocemos su aspecto gracias a la relación impresa de los funerales, en la que se describen con detalle, y al grabado del túmulo que la acompaña realizado por Manuel Peleguer, y dibujado por Juan Anselmo Alfonso, artífice del diseño y proyecto del túmulo. El catafalco fúnebre era descrito en el Elogio fúnebre, que en las exequias de la Reyna Nuestra Señora Doña María Josefa Amalia de Sajonia, celebradas por el Real Acuerdo de la Audiencia de Valencia, en la Iglesia del Convento del Carmen, el día 15 de junio de 1829, en el que se recogía el texto y oración que a la reina fallecida dedicaba M. R. P. Fray Vicente

53 La Audiencia remitió a la Academia de San Carlos una copia del Elogio Fúnebre de la Reina, y en el acta de su Junta Ordinaria de 6 de septiembre de 1829 se acordó, dar las gracias a D. Nicolás Gómez Villaboa, regente de la Real Audiencia y Académico de Honor, deliberando que "Se conservasen dos exemplares en el Archivo, se repartieron las restantes una al Excmo. Señor Dn. Salvador de Perellós, el segundo para que se remita al Sr. Dn. Vicente López Director General y el tercero al Sr. Miguel Parra que hace sus veces, y el quarto para que se turne y puedan leerle los profesores". ARASC. Libro de Acuerdos en limpio de las Juntas ordinarias desde enero del año 1828 hasta noviembre de 1845. Acta de 6 de septiembre de 1829.

54 HERNÁNDEZ MEDINA, Vicente, 1829. 


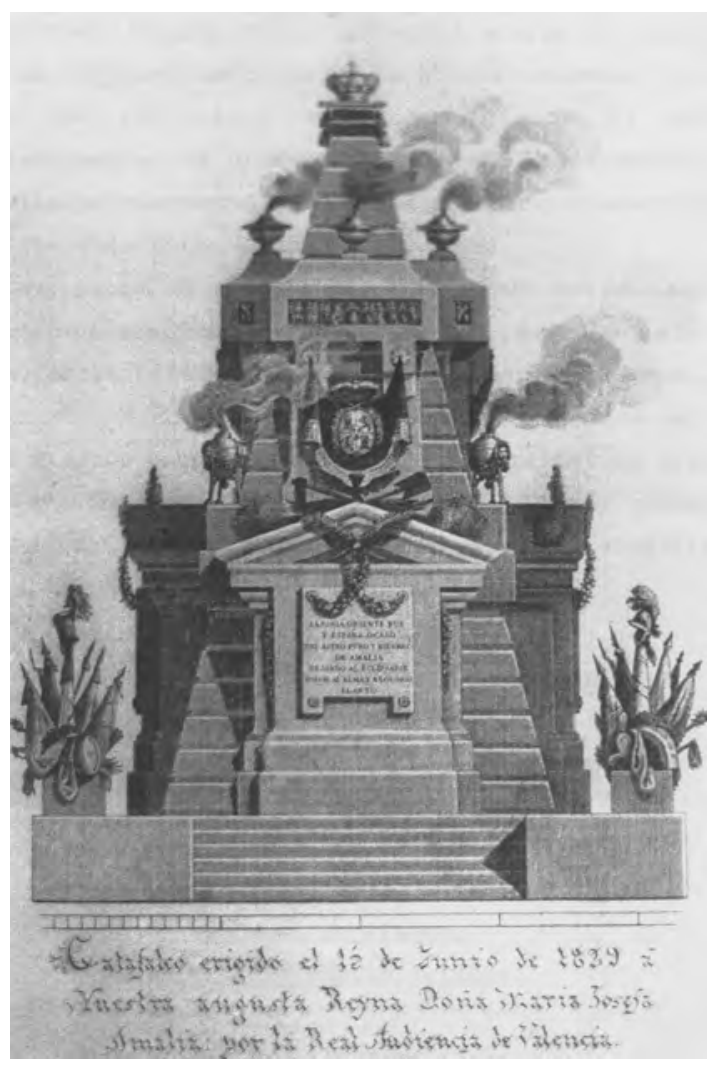

Fig. 9. Juan Anselmo Alfonso lo dibujó, Manuel Peleguer lo grabó. HERNÁNDEZ MEDINA, Vicente. Elogio Fúnebre que en las exequias de la Reyna Nuestra Señora Doña María Josefa Amalia de Sajonia celebradas por el real Acuerdo de la Audiencia de valencia en la iglesia del Convento del carmen el dia 15 de junio de 1829. Imprenta Benito Monfort. Valencia, 1829.

Hernández Medina..$^{55}$ En su oración titulada Exemplum virtutis et fortitudinis/ Fue egemplar de virtud y fortaleza (libro II de los Macabeos, cap. 6), el teólogo insistía en ensalzar las virtudes de la reina fallecida:

que finó ya doña María Josefa Amalia; y hemos perdido á nuestra gran Reyna. Pérdida inconsolable; pérdida para todos los buenos españoles la mas sensible y dolorosa, y para mí la mas afligente y amarga. Es para los españoles del mayor sentimiento, porque todos han perdido una Reyna incomparable, una Soberana la mas amante de sus vasallos, una madre la mas tierna para sus hijos, una mano bienhechora y liberal para los pobres, una consoladora para los afligidos, una regla de las costumbres, y un modelo de todas las virtudes. [...] Exemplum virtutis, et fortitudinis. Egemplar de virtud, por las muchas que adornaron su alma en medio de la corrupción del mundo. Egemplar de fortaleza, por su firme adhesión á la doctrina católica en medio de las pestilentes novedades del siglo. Nada más [...].

Por otro lado, es uno de los pocos eruditos que hace mención al origen germánico de la reina y su pertenencia a la religión católica y su rechazo al protestantismo luterano:

¿Y acaso este Trono tan augusto, tan ejemplar, tan lustroso, elevado sobre todos los Tronos, el embeleso de las Naciones, y la envidia de la Europa, le empañaría doña María Josefa Amalia con algún borrón ó tizne traído de los países del Norte? ¡Ah, Señores, qué es lo que he dicho! No: nuestra Reyna lejos de traer á la España, la funesta caja de Pandora, ni algún hálito dañino y pegajoso; trajo la urna de oro llena de aromas y olorosos perfumes, tanto al agrado de Dios, como al gusto de su Católico esposo... Una Reyna humilde, una Reyna modesta, una Reyna prudente, una Reyna devota, piadosa, religiosa, benéfica, sin rastro de soberbia, de altanería, ni de orgullo; sin ostentación de Magestad, de Soberanía, ni de Imperio, la califiqué por una santa, tal me pareció entonces, y tal se ha mostrado en su corto Reynado ...

Del mismo modo que en otras ocasiones, los paralelismos bíblicos son reincidentes, especialmente los alusivos a Ester ante Asuero, así como las referencias clásicas y al pasado reciente de la monarquía hispánica:

si la célebre Porcia decía, que fuera de su marido Marco Bruto nada la solicitaba en Roma; á María Josefa Amalia nada la llenaba en España sino solo su Fernando. María Amalia cual otra Doña Isabel con Fernando $\mathrm{V}$, siguió fielmente todos los pasos de su amado, bien ásperos y espinosos, y dejando para el esposo algunos breves intervalos de quietud y de placer, si acaso los ha tenido; se reservó para sí sola las hieles y amarguras de la parte más querida de su alma.

${ }^{55}$ HERNÁNDEZ MEDINA, Vicente, 1829. Al final del libro, junto a una hoja en la que se describe el catafalco: Construcción conformada por dos cuerpos decrecientes, engarzados por una pirámide en el frente. En el vértice se decora con la corona y el cetro. En la parte central muestra escudo regio. En la parte inferior, bajo frontón, va una placa con la siguiente inscripción: "SAJONIA ORIENTE FUE Y ESPAÑA OCASO DEL ASTRO PURO Y BIENHECHOR DE AMALIA DEJANDO AL ECLIPSARSE DOLOR AL ALMA Y A LOS OJOS LLANTO". En las repisas se disponen pebeteros y guirnaldas. En los extremos del basamento se colocan insignias y banderines. Fray Vicente Hernández Medina pertenecía a la orden de predicares, era maestro "en sagrada Teología, Predicador titular y perpetuo de la Ciudad de Alicante, teólogo consultor del Ilustrísimo Sr. Obispo de Tortosa, Examinador Sinodal del Obispado de Orihuela y Arzobispo de Valencia, y actual Regente de Estudios del Convento de San Felipe". Había tenido la oportunidad de coincidir con la reina durante la visita de los monarcas de la ciudad de San Felipe (Xàtiva). Por otra parte, hace alusión a la educación de la reina a manos de su tutor en Sajonia, el P. Grachi, jesuita confesor de las "personas Reales de Sajonia" y que fue quien la acompañó en su viaje a España para contraer nupcias. 
Se trata de un texto altamente significativo, ya que es una de las escasas ocasiones en las que se alude de manera clara al periodo del Trienio Liberal (1820-1823) y al cautiverio que los monarcas pasaron durante ese periodo. Durante esos años, Fernando VII sufrió prisión, al ser considerado traidor a la nación, tras incumplir su juramento a la constitución española. Un episodio que vivió la joven reina casi nada más llegar a España, en 1819, y que, ahora, en su muerte, se recuerda como un momento aciago que los monarcas vivieron juntos.

El monumento presentaba un diseño piramidal, coronado por la corona real, sobre almohadones negros en señal de luto. El cuerpo almohadillado de la pirámide se sostenía sobre un zócalo y graderío o escalinata, sobre el que se colocaron trofeos militares, dispuestos sobre plintos. En su frente se dispusieron cuatro templetes clásicos con frontispicio que albergaba la lápida con las inscripciones laudatorias en honor de la difunta María Josefa Amalia, y dos guirnaldas con varios atributos alusivos a la muerte, como el reloj alado, las ramas de ciprés, guadañas, etc. La pirámide se hallaba interrumpida por dos cuerpos cuadrangulares. En el primero se situaron trípodes con flamas, y en los cuatro frentes los escudos de armas de España, Sajonia y Valencia. En el tercer cuerpo de la pirámide se colocaron cuatro bajorrelieves que representaban la llegada de María Josefa Amalia como reina de España, la caridad de la reina con los pobres, la hospitalidad y misericordia con los enfermos, y, por último, la personificación del tiempo conduciendo a la Reina al sepulcro y España llorando su partida. La mayor curiosidad de este monumento es la eliminación del féretro o urna funeraria en alusión a la real persona difunta, una novedad en este tipo de monumentos. En este monumento los elementos simbólicos reiteran la introducción de un lenguaje luctuoso romántico similar al que ya se había utilizado en el caso de los de Isabel de Braganza, pero destaca la reiteración de las imágenes que construyen a la reina fallecida como una reina dechado de virtudes, especialmente asociadas a sus labores de caridad y beneficencia.

El 17 de junio de 1829 se celebraron las exequias de la reina, por la Universidad de Valencia, en la Capilla de Nuestra Señora de la Sabiduría, siendo su orador Jorge Comín, "elector general del Real y Militar Orden de la Merced, doctor y catedrático perpetúo de Instituciones de Teología de primer año y moderante de oratoria de la misma Univer- sidad, examinador sinodal del Arzobispado de Valencia, Predicador honorario de la Excma. Ciudad, socio de número de en la Real Sociedad de Amigos del País, Censor y revisor Real de libros". La iglesia de la Virgen de la Sapiencia de la Universidad fue decorada en su interior y portada con telas negras y trofeos con las armas reales de España y Sajonia, llegando incluso a enlutar el pavimento. ${ }^{56}$ El monumento funerario se levantó en el presbiterio frente al altar, de fabricación sencilla. Constaba de dos cuerpos, el primero formado por cuatro arcos rebajados que sostenían una bóveda bajo la que se albergaba la urna sepulcral, rodeada de símbolos alusivos a la fugacidad de la vida y al tiempo. En los capiteles de las columnas dóricas se representaron los dominios de Fernando VII en ambos hemisferios. Sobre este cuerpo se situó una columna o pirámide truncada, en cuyos frentes se representaron los símbolos de las ciencias y las artes en ademán de llorar la muerte de su Augusta protectora, en bajorrelieve. Festones dorados y trofeos militares pendientes de las columnas, flameros, genios afligidos completaban la decoración del monumento, que se cubría con un cortinaje negro, con cordones de oro. En este caso, uno de los elementos más destacados será la imagen proyectada de la reina asociada a su labor como protectora de las artes y de la ciencia, un lenguaje que se ajustaba a la naturaleza de la institución, la Universidad, a la que el catafalco estaba destinado. Por otro lado, en este monumento destaca curiosamente la utilización de elementos alusivos al carácter imperial de la monarquía española, en un momento de declive territorial, producto de los procesos independentistas americanos.

Joaquín Esteve de San Miguel, vicario general de la orden de las Escuelas Pías de Valencia será el encargado de leer la Oración fúnebre dedicada a la reina por la Real Maestranza de Valencia. En este opúsculo, se hace especial incidencia en el paralelo de la joven reina con la Judith bíblica, insistiendo en conceptos como "bello dechado de la justicia cristiana", "virtud e inocencia", "angelical", incidiendo en las virtudes paralelas con Noemí, o con las de Ruth: "la amable y virtuosa Ruth: scit enim omnis populus, mulierem te ese virtutis: porque sabía todo el pueblo español, que tenía una Reyna adornada de toda virtud, y por eso en cualquier especie de conflictos públicos ya que no con las palabras decíamos tácitamente lo que decían los de Betulia á su virtuosa y celebrada Judith", ${ }^{57}$ al tiempo que se la comparaba con Amalia

\footnotetext{
${ }^{56}$ COMÍN, Jorge, 1829.

57 ESTEVE DE SAN MIGUEL, Joaquín, 1829, p. 3.
} 
de Sajonia, esposa de Carlos $1 I^{58}$ y su devoción católica con Catalina de Siena, Magdalena de Pazzis y Santa Teresa de Jesús, o con la "virtuosa Eduvigis" y con Isabel de Portugal. ${ }^{59}$

En el ámbito artístico, el Real Cuerpo de la Maestranza volvió a confiar en el pintor de cámara, Miguel Parra, quien en 1819 había realizado los monumentos erigidos en honor de Isabel de Braganza y de María Luisa de Parma y Carlos IV, padres de Fernando VII, y que en ese momento era Director general, en ausencia de Vicente López, de la Academia de San Carlos de Valencia, para el diseño del monumento funerario y las decoraciones efímeras (Fig. 9). El monumento se levantó el 1 de julio en la iglesia de las Escuelas Pías. Miguel Parra se ocupó de realizar las trazas y la parte pictórica e ilusionista del cenotafio, imitando mármoles, jaspeados, dorados, bronces, bajorrelieves etc.; mientras que la realización de las esculturas, en yeso o escayola, corrió a cargo del escultor José Piquer, y los versos e inscripciones fueron realizados por Juan Nicasio Gallego, presbítero y miembro de la Real Academia de San Fernando de Madrid. Como marca la tradición, la iglesia se enlutó con diversas decoraciones, pabellones negros con borlas y flecos dorados e inscripciones alusivas a la reina difunta. El catafalco se erigió en el centro de la iglesia, bajo su gran cúpula, lo que permitió construir y diseñar un monumento de grandes dimensiones, de unos 21 metros. Sobre un zócalo o base cuadrada, se alzaba el túmulo monumental, rodeado en los cuatro ángulos por pedestales octogonales con grupos de niños "en mármol blanco" con actitudes dolientes, sosteniendo sobre sus cabezas las tazas con las piras funerarias. La escalinata principal estaba adornada con el estandarte, timbales, lanzas e instrumentos y trofeos militares de la Real Maestranza. El cuerpo principal, almohadillado, de planta cuadrada, sostenía los cuatro arcos y la bóveda, bajo la que se situó la urna real, cubierta por manto de terciopelo negro, culminado por la corona real sobre dos almohadones enlutados. Sus frentes se decoraron con ocho estatuas alegóricas de mármol blanco, sedentes, representando a las virtudes de la difunta soberana: La Fe, la Caridad, la Esperanza, la Fortaleza, la Prudencia, la Templanza, la Modestia y la Paciencia, acompañadas de inscripciones, y representadas según "los conocidos atributos que las distinguen. (...) la Modestia con la frente inclinada y los ojos bajos, envuelta en su largo ropaje, y la Paciencia, fijando la planta sobre ásperos abrojos, y esperando la más dulce resignación en su rostro apacible" ${ }^{60}$ como expresión de las principales virtudes de la reina fallecida, que de nuevo se reiteran en el lenguaje artístico utilizado. La bóveda se remataba por cuatro áticos en sus frentes, decorados con los escudos de armas de España, entre trofeos: los de Sajonia y los de la Real Maestranza, en ambos laterales. El catafalco culminaba en un cuerpo en forma de zócalo con cuatro trípodes y candelabros que piramidaban el grupo de luces en torno al segundo cuerpo, constituido por una gruesa columna dórica, ceñida por un cuerpo octogonal, en cuyos laterales se dispusieron genios afligidos ante la muerte de la reina, que representaban el Amor conyugal sin la venda en los ojos, y con las alas cortadas, apoyado con tristeza en su yugo hecho pedazos; el Himeneo con la antorcha vuelta y apagada; el genio de las bellas artes con los instrumentos del dibujo: el lápiz y el papel, y el genio de la Poesía con la llama ardiente sobre su cabeza, y con la lira con las cuerdas rotas, a las que contempla con desconsuelo, creando un programa alegórico e iconográfico completo y de gran complejidad. Coronando el monumento, la personificación de la Muerte, colocada sobre el capitel de la columna, mostrando su triunfo, y aplastando con el pie los bienes materiales, acompañada por emblemas alusivos a la inestabilidad de la vida y a la reina. Un monumento que, por la presencia de la muerte coronando el conjunto, recordaba el que, en honor de Isabel de Braganza, se levantó en Roma en 1819 y que había sido difundido a través del grabado (Fig. 10).

También el Ayuntamiento de Valencia celebró honras fúnebres, el 10 de julio de 1829, en el interior de la catedral de Valencia. El interior se decoró con paños negros e inscripciones, al igual que fachada de la catedral. En el crucero, bajo el cimborrio, se levantó un espectacular monumento fúnebre, de unos 18 metros de altura, que conocemos gracias a un grabado realizado por Tomas Rocafort sobre dibujo de José Vicente Pérez, que acompañaba a la publicación impresa de las exequias y del que se conserva un dibujo en el Museo de la Ciutat de Valencia (Figs. 11 y 12). Aunque en esta relación publicada, en la que se describe el catafalco, Elogio fúnebre que en las solemnes exequias de S.M. católica la Reyna Nuestra Señora Doña María Josefa Amalia de Sajonia, celebradas por el Excmo. Ayuntamiento e Ilmo. Cabildo eclesiástico

58 ESTEVE DE SAN MIGUEL, Joaquín, 1829, p. 10.

59 ESTEVE DE SAN MIGUEL, Joaquín, 1829, p. 17 y 19.

60 ESTEVE DE SAN MIGUEL, Joaquín, 1829. 


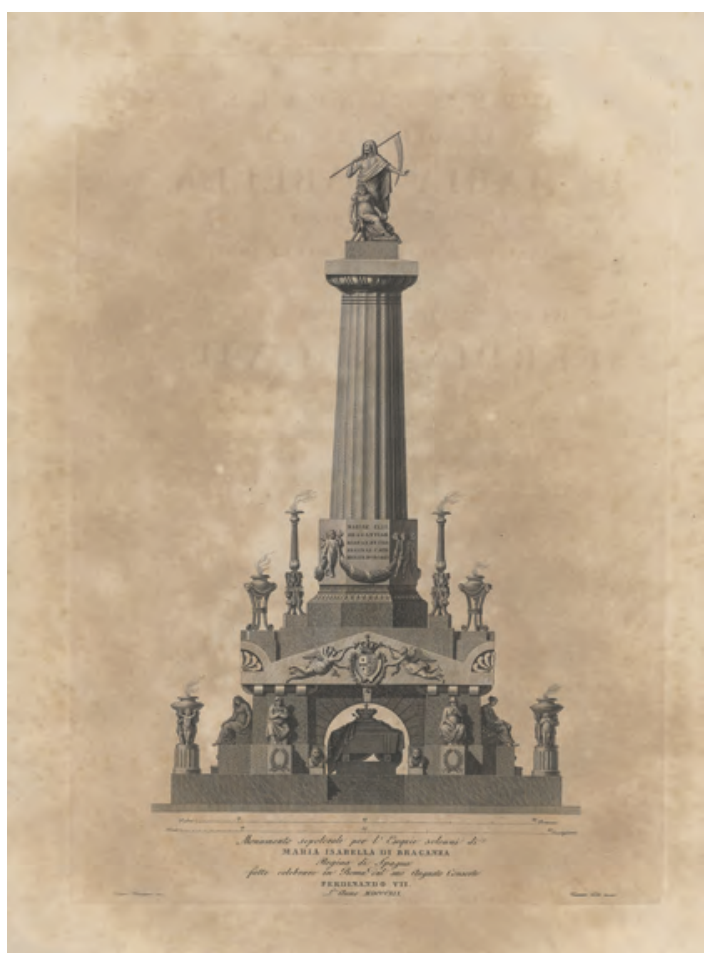

Fig. 10. Diseñado por Isidoro Velázquez y grabado por Vicenzo Feoli. Cenotafio en memoria de la reina Isabel de Braganza en la iglesia de San Ignacio en Roma. GUATTANI, Giuseppe Antonio. Pompa funebre per le solenni esequie di Maria Isabella di Braganza regina delle Spagne, e delle Indie fatte celebrare in Roma da S.M.C. l'augusto consorte Ferdinando VII l'anno 1819. Roma, 1820.

de Valencia en la Iglesia metropolitana, ${ }^{61}$ no se especifica el artista encargado de las obras, hemos de suponer que el proyecto y construcción fueron encargados a José Vicente Pérez que firma el dibujo, dejando constancia de que lo "inventó" o dio las trazas, ${ }^{62}$ además de presentar enormes similitudes con el que realizó en 1819 para las exequias que organizó el consistorio valenciano para honrar a Carlos IV, María Luisa de Parma e Isabel de Braganza; de hecho, era bastante habitual aprovechar elementos de los catafalcos fúnebres anteriores como hemos visto en el caso madrileño (Fig. 13).

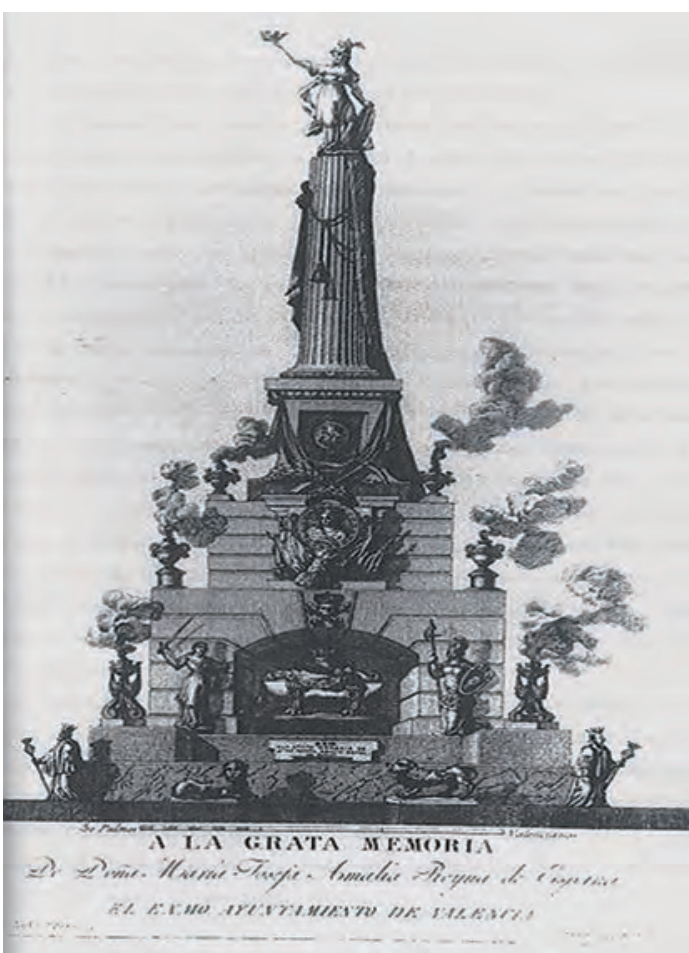

Fig. 11. Dibujado por José Vicente Pérez. Grabado por Tomás Rocafort. Cenotafio erigido en la Catedral para las exequias de $\mathrm{M}^{\mathrm{a}}$ Josefa Amalia de Sajonia por el Ayuntamiento de Valencia, 1829.

Se trata de un cenotafio compuesto por diversos cuerpos escalonados que disminuyen progresivamente en altura, rematado por una columna truncada, sobre la que se situó la representación simbólica de la Lealtad de Valencia, personificada en una matrona, que sustenta la corona real y el escudo de Valencia. El cenotafio se elevaba sobre un gran zócalo, en cuyos lados se colocaron cuatro heraldos con las armas de la ciudad de Valencia, y otros tantos trípodes para las flamas, además de figuras de esfinges en diversas actitudes. Sobre el un primer cuerpo arquitectónico almohadillado se cobijaban cuatro arcos rebajados, que daban paso

${ }^{61}$ ELOGIO, 1829, publicado en la imprenta de Benito Monfort. Se especificaba que el coste de la decoración alcanzó unos 10.000 reales vellón.

62 Esta suposición toma cuerpo si tenemos en cuenta que José Vicente Pérez es uno de los artistas especializados en decoraciones efímeras y en pintura de decorados y escenografías que mayor renombre alcanzarán en Valencia, realizando numerosos monumentos efímeros en la ciudad con ocasión de los festejos celebrados ante las visitas reales o el anuncio de noticias relacionadas con la familia real. 


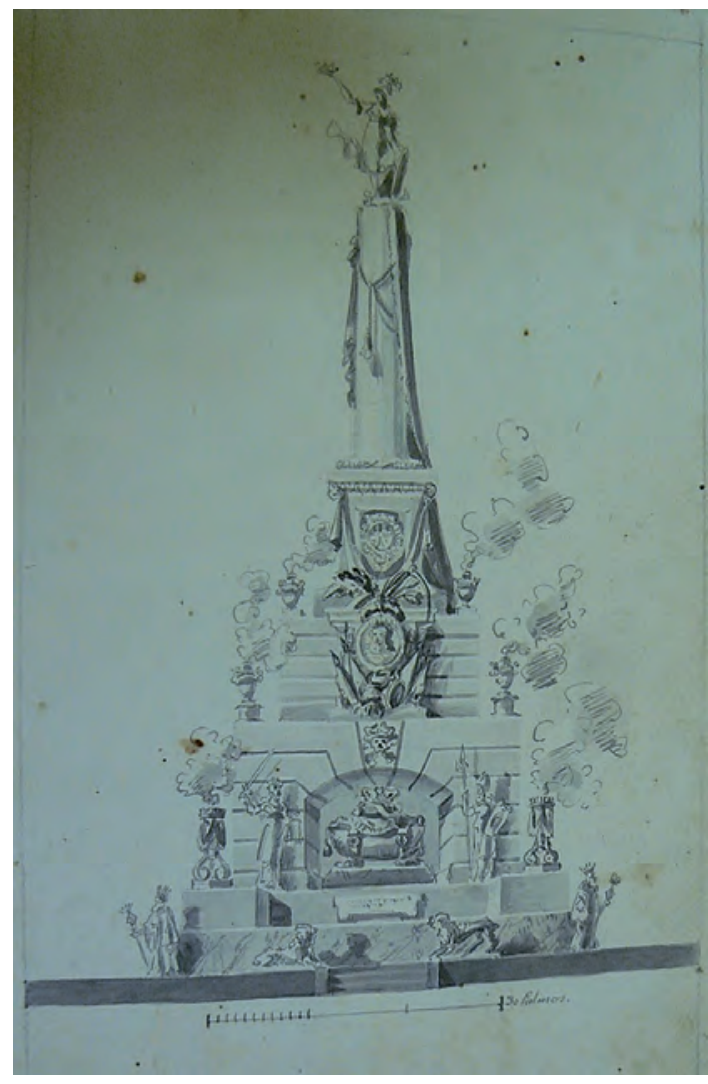

Fig. 12. José Vicente Pérez. Dibujo para el Cenotafio erigido en la Catedral para las exequias de $\mathbf{M}^{\mathrm{a}}$ Josefa Amalia de Sajonia por el Ayuntamiento de Valencia, 1829. Museo de la Ciutat, Valencia.

a la bóveda bajo la que se situaba el féretro o urna funeraria simbólica, colocando sobre ella el manto y la corona real. Sus frentes se decoraron con esculturas alegóricas de las virtudes de la reina, distinguiéndose en la lámina la Justicia y la Fortaleza, con los atributos iconográficos codificados por Ripa. La Justicia era descrita en el Elogio como "recta, que no se pliega ni a la amistad ni al odio, lleva la espada en alto, y la balanza", mientras que la Fortaleza de ánimo y cuerpo se representaba como una mujer armada con un escudo con la cabeza de león, casco y lanza. En las claves de los arcos se insertaron símbolos de la muerte, como las tibias entrecruzadas o la calavera coronada, haciendo uso de los emblemas y vanitas recopilados y utilizados desde el barroco, y los escudos de España y Sajonia. En los ángulos se colocaron cuatro jarrones con flamas. En el segundo cuerpo seguía una decoración similar, con los pebeteros humeantes en sus ángulos, mientras que en sus cuatro frentes se colocaron los retratos de la reina María Josefa Amalia en medallones, realizados simulando bajorrelieves y

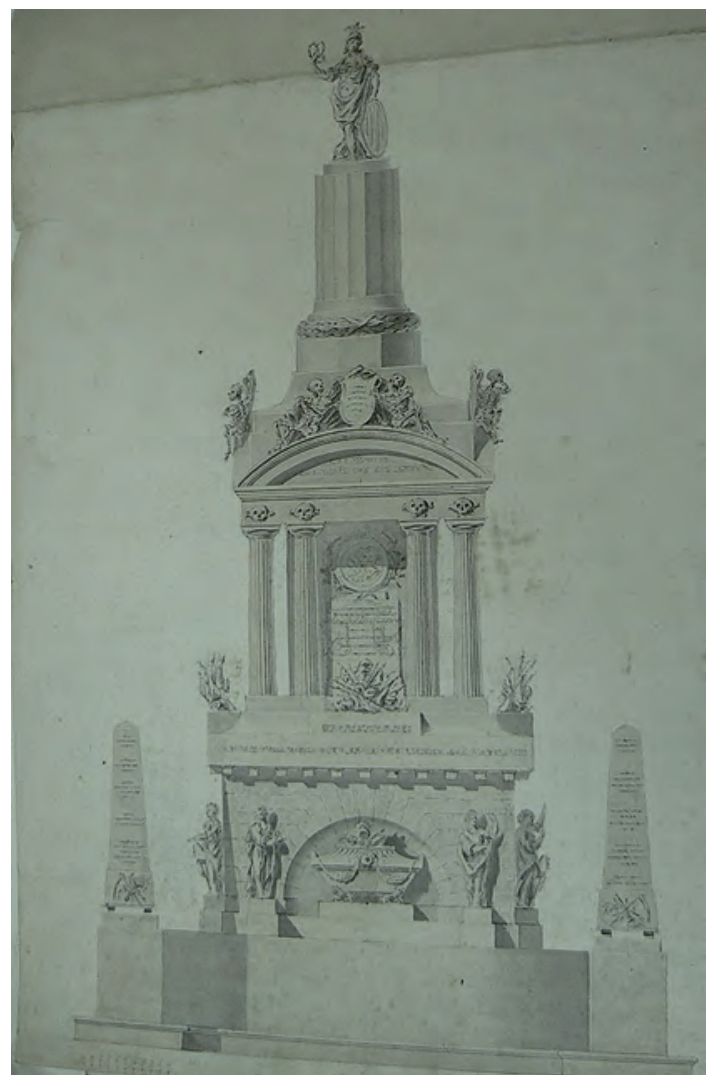

Fig. 13. José Vicente Pérez. Cenotafio erigido en la Catedral para las exequias de Isabel de Braganza, Carlos IV y María Luisa de Parma por el Ayuntamiento de Valencia, 1829.

acompañados por alegorías de la poesía, trofeos militares y símbolos de la mortalidad, como la rama de ciprés y la guadaña. Sobre este cuerpo se levantó la columna estriada, sobre un elevado pedestal, cuyos frentes se decoraron con las armas de España y Sajonia. Este tipo de estructuras piramidales o en forma de obelisco o columnas truncadas fueron muy utilizadas por este artista, y por las que alcanzó gran renombre, especializándose en el diseño y construcción de obeliscos efímeros en los festejos que se celebraban en la ciudad de Valencia.

A pesar de las numerosas exequias, el recuerdo de la joven reina fue efímero. Tan solo dos meses después de su muerte, Fernando VII volvía a casarse, esta vez con su sobrina María Cristina de Borbón. La necesidad de dar un heredero a la Corona y asegurar la continuidad de la monarquía eran la prioridad más urgente. No obstante, el análisis de la imagen de la reina, a través de los textos y monumentos que concurrieron en sus funerales, da 
muestra de la construcción de la imagen de la tercera esposa de Fernando VII: María Josefa Amalia de Sajonia. Estas imágenes encarnan, de manera contundente, la instrumentalización que los poderes monárquicos, defensores del absolutismo, hicieron de la reina: en toda la panoplia de imágenes, sermones y relaciones, la reina aparece encarnada como modelo perfecto de reina doméstica, virtuosa, fiel, amante y obediente a su esposo, católica y benéfica, hasta el punto que se convirtió en ejemplo de esposa virtuosa y en paradigma de mujer piadosa y devota. ${ }^{63}$

\section{Bibliografía}

AGULHON, Maurice. Marianne au combat. L'imagerie et la symbolique républicaines de 1789 à 1880. Paris: Flammarion, 1979.

ALBA PAGÁN, Ester. La pintura y los pintores valencianos durante la Guerra de la Independencia y el reinado de Fernando VII (1808-1833). Tesis doctoral. Valencia: Universitat de València, 2004.

ALBA PAGÁN, Ester. "Representaciones de la reina en la retórica visual del absolutismo fernandino: la imagen de María Josefa Amalia de Sajonia como estrategia de la alianza entre el trono y el altar". Ars longa: cuadernos de arte, 2016, n. 25, p. 201-220.

ALBA, Ester; PÉREZ OCHANDO, Luis (eds.). Me veo luego existo. Mujeres que representan, mujeres representadas. Madrid: CSIC, 2015.

ALBA, Ester; PÉREZ OCHANDO, Luis. "La historia cultural desde la perspectiva de las artes visuales y la perspectiva de género". En: De-construyendo identidades: la imagen de la mujer desde la modernidad. València: Universitat de València, 2016.

AMAT, Cristóbal. Oración fúnebre que en las reales exequias celebradas en la Santa Iglesia Catedral de Cuenca el dia 16 de junio del presente año de 1829, en sugfragio del alma piadosa de la muy augusta señora Doña Maria Josefa Amalia de Sajonia, reina de España é Indias, dijo el Doctor Don Cristóbal Amat y Zocoli, dignidad de Capellan mayor y canónigo magistral de dicha santa Iglesia. Cuenca, Imp. Hijos de la Madrid, 1829.

ARBIZU Y ECHEVERRIA, Xavier María de. Lamentación y afectuoso sentimiento que la Muy noble y leal ciudad de Pamplona, cabeza del fidelísimo reino de Navarra, consagró a la memoria de la Señora Doña Isabel Francisca de Braganza y Borbón... Pamplona, 1819.

ARRAMBIDE, Juan Manuel. Epístola al Rey Nuestro Señor, con motivo de la temprana y dolorosa muerte de la Reina Nuestra Señora Doña María Isabel de Braganza. Madrid: Imp. De Repullés, 1829.

ARRAZOLA, Lorenzo. Poesías ó Cantos lúgubres á la sensible y prematura muerte de nuestra augusta soberana Doña María Josefa Amalia de Sajonia. Valladolid, 1829.

BILLING, Michael; VAN OSTA, Jaap. "The Emperor's New Clothes. The Reappearance of the Performing Monarchy in Europe, C. 1870-1914". En: DEPLOIGE, J. (dir.). Mystifiying the Monarch: Studies on Discourse, Power, and History. Amsterdam: University Press, 2007.

BLOCH, Marc. Los reyes taumaturgos. México: Fondo de Cultura Económica, 1993.
BOLUFER, Mónica. "Lo íntimo, lo doméstico y lo público: representaciones sociales y estilos de vida en la España Ilustrada". Studia Historica. Historia Moderna, 1998a, p. 85-116.

BOLUFER, Mónica. Mujeres e llustración. La construcción de la feminidad en la España del siglo XVIII. València: Diputació de València, 1998b.

BRICE, Catherine. Monarchie et identité nationale en Italie: 1861-1900. Paris: Editions de l'École des hautes études en sciences sociales, 2010.

BURDIEL, Isabel. "The Queen, the Woman and the Middle Class. The symbolic failure of Isabel II of Spain". Social History, 2004, 3, vol. 29.

BURDIEL, Isabel. "El descenso de los reyes y la nación moral. A propósito de los Borbones en pelota". En: Los Borbones en Pelota. Zaragoza: Institución Fernando el Católico, 2012.

CABRERA SENDRA, Inés. "La arquitectura en Valencia durante la crisis del Antiguo Régimen (1812-1833)". En: MíNGUEZ, V. (coord.), Las artes y la arquitectura del poder. Castellón: Universitat Jaume I, 2013, p. 685-698.

CALVO MATURANA, Antonio. "The image of European consorts in the late eighteenth century: Marie Louise, Queen of Spain, trougth the looking mirror". En: Actas del III Congreso Internacional sobre el Duque de Wellington y su época, Universidad de Southampton, 2006.

CALVO MATURANA, Antonio. María Luisa de Parma: Reina de España, esclava de un mito. Granada: Col. Feminae, 2007.

CALVO MATURANA, Antonio. "María Antonia de Borbón e Isabel de Braganza: el valor simbólico de las dos primeras mujeres de Fernando VII". en Feminis$\mathrm{mo} / \mathrm{s}, 16$, diciembre, 2010, p. 13-38.

CILLA, Vicente de. Elogio fúnebre que las solemnes ecsequias celebradas en sufragio del alma de la Augusta Reina de España Doña María Josefa Amalia de Sajonia á impulsos de la piedad de M. Iltre. Y de todos los demás empleados en la Baylia general del Real Patrimonio de la provincia de Cataluña. Barcelona, Imprenta de la viuda e hijos de D. Antonio Brusi, 1829.

COMín, Jorge. Exequías a la Reyna de las Españas doña María Josefa Amalia de Sajonia, celebradas por el Claustro de Catedráticos de la Universidad de Valencia en su Capilla de Nuestra señora de la sabiduría el día 17 de junio de 1829 y Elogio Fúnebre. Impr. Benito Monfort. Valencia, 1829.

COSANDEY, Fanny. "Les femmes en politique, transgression ou alternative ? Les rapports de pouvoir à la cour de France (XVle-XVIlle siècles)". ABBOTT, Fanny; PIBRI, Eva (dirs.). Féminité et masculinité altérées : transgression et inversion des genres au Moyen Âge, "MicrologusLibrary" n. 78. Florencia: Sismel Edizioni del Galluzzo, 2017, p. 301-322.

COSANDEY, Fanny. La Reine de France. Symbole et Pouvoir, XV-XVIII siècle. Paris : Gallimard, 2000.

DESCRIPCIÓN del cenotafio erigido para las reales exequias de la Reina Nuestra Señora D.a. María Josefa Amalia de Sajonia: celebradas en el día 28 de julio en la iglesia del Real Convento de S. Francisco el Grande de esta corte. Madrid: Imprenta de León Amarita, 1829a.

DESCRIPCIÓN del cenotafio erigido en la Iglesia Parroquial de Santa Maria del Mar de Barcelona para las Solemnes Exequias que la Real audiencia de Cataluña ha celebrado por la muerte de la Reina nuestra Señora Doña María Amalia de Sajonia [Barcelona: s.n., 1829b].

${ }^{63}$ ALBA, Ester, 2016, p. 201-220. 
DESCRIPCIÓN de las solemnes exequias que celebró en $1^{\circ}$ de julio de este año por el alma de Nuestra Augusta Soberana Da. María Josefa Amalia de Sajonia Q.E.P.D. la Real Maestranza de Valencia [Valencia]: Imprenta de D. Benito Monfort. 1829c.

DE LOS DOLORES, Manel. Oración fúnebre que en las ecsequias funerales celebrades por disposicion de la Real Junta de Comercio de Cataluña (...) en sufragio de la Señora $D^{a}$ Maria Josefa Amalia (...). Barcelona, Vídua d'Agustí Roca, 1829.

DOMĖNECH, Albert. "Els Castrum doloris en els gravats i les relacions impreses de la Catalunya borbònica de I'Antic Règim (1700-1834). Una eina per aprofundir en l'art efímer". eHumanistalIVITRA, 2018, 14, p. 223- 271.

ELOGIO fúnebre que en las solemnes exequias de S.M. Católica la Reyna Nuestra señora Doña María Josefa Amalia de sajonia, celebradas por el Excmo. Ayuntamiento e Ilmo. Cabildo eclesiástico de Valencia en la iglesia metropolitana dia 10 de julio de 1829. Valencia: Imprenta de Benito Monfort, 1829.

ESTAPER, Martín. Elogio fúnebre que en las exequias de la Reina y Señora doña Josefa Amalia de Sajonia celebradas por el Real Acuerdo de la Audiencia de Cataluña en la parroquial Iglesia de Sta. María del Mar el día 3 de junio de 1829. Barcelona: Imprenta de Juan Francisco Piferrer, impresor de S.M., 1829.

ESTEVE DE SAN MIGUEL, Joaquín. Oración Fúnebre en las solemnes Exequias de la Católica Reyna de las Españas Doña María Josefa Amalia de Sajonia, celebradas por la Real Maestranza de Valencia en la Iglesia de las Escuelas Pías de la misma el día 1 de Julio del año 1829. Valencia: Imprenta de Benito Monfort, 1829.

ESCEQUIAS [sic] que la Muy Noble y Muy Leal ciudad y Reyno de Mallorca hizo en la Iglesia catedral de la isla el dia 17 de julio de 1829 a la Católica Magestad de la Reyna Nuestra Señora Doña María Josefa Amalia. Palma: Imprenta de Buenaventura Villalonga, Año de 1829.

FAGIOLO DELL'ARCO, Maurizio. Corpus delle Feste a Roma 2. Il Settecento e l'Ottocento. Firenze: De Luca Editori d'Arte, 2005.

FITZPATRICK, Matthew P. "Performing monarchy The Kaiser and Kaiserin's voyage to the Levant, 1898". En: ALDRICH, Robert and MCCREERY, Cindy (eds.). Royals on tour. Politics, Pageantry and Colonialism, Manchester University Press, 2018.

FRADENBURG, Olga. Women and Sovereignty. Edinburgh University Press, 1992.

GARCÍA DE LOS SANTOS, Ramón. Elogio fúnebre que en las Solemnes exequias que celebró la Real e llustre Congregación del Santísimo Cristo de la Obediencia por el alma de su augusta Hermana mayor María Josefa Amalia de Sajonia, Reina de España y sus Indias, oficiando de Pontifical el IImo D. Pablo Abella, Obispo de Tiberiópolis y Auxiliar de Madrid, Prefecto de la misma Congregación, dijo en la Real y Patriarcal Iglesia de Nuestra Señora del Buen Suceso de esta corte, el día 5 de julio del presente año de 1829, el R. P. Predicador Fr. Ramon García de los Santos... Madrid: Imprenta de D. Eusebio Aguado, 1829.

GARGANTÉ LLANES, Maria. Festa, arquitectura i devoció a la Catalunya del Barroc. Barcelona: Publicacions de l'Abadia de Montserrat, 2011.

GONZÁLEZ, Juan. Oración fúnebre que en las solemnes exequias celebradas por el Excmo. Ayuntamiento de esta muy noble, muy leal, muy heroica, imperial y coronada villa de Madrid... por la sentida muerte de Nuestra Augusta Soberana Doña Isabel de Braganza y Borbón..., Madrid, 1819.
GONZÁLEZ TORNEL, Pablo; ALBA PAGÁN, Ester. "Roma 1819: dos reinas, dos funerales y un cadáver. Las exequias de María Luisa de Borbón y María Isabel de Braganza". Reales Sitios: Revista del Patrimonio Nacional, 2013, n. 195, p. 50-64.

HENARES CUÉLLAR, Ignacio Luis. "El arte del siglo XIX como modelo historiográfico en la formación del Historiador del Arte". En: SAURET, Teresa (ed.). EI Siglo XIX a reflexión y debate. Málaga: Universidad de Málaga, 2013, p. 37-54.

HERNÁNDEZ MEDINA, Vicente. Elogio Fúnebre que en las exequias de la Reyna Nuestra Señora Doña María Josefa Amalia de Sajonia celebradas por el real Acuerdo de la Audiencia de valencia en la iglesia del Convento del carmen el dia 15 de junio de 1829. Dijo el MRP. FRAY Vicente Hernández Medina. Valencia: Impenta de Benito Monfort, 1829.

HONRAS que en piadosa memoria de las virtudes de la Reina de las Españas Da Maria Josefa Amalia de Sajonia celebraron en el RI. Monast ${ }^{\circ}$ de S. Geronimo de Granada el dia 7 de agosto el Exmo. Sr. Capitán General, SS. Generales, bajo la dirección del Brigadier de Infantería D. Manuel Trebijano, y del Gobernador de la Rl. Fortala. de la Alambra D. Franco. Sales Serna encargados de este tributo fúnebre, 1829.

HUNT, Lynn. Eroticism and the Body Politic. Baltimore: John Hopkins University Press, 1991.

HUNT, Lynn. Politics, Culture \& Class in the French Revolution. Londres: University of California Press, 1986.

JONES, Amelia (ed.). The feminism and the visual culture reader. Londres: Routledge, 2010.

KANTOROWICZ, Ernst. H. Los dos cuerpos del rey: Un estudio de teología política medieval. Madrid: Alianza, 1985.

KLÉBER MONOD, Paul. El poder de los reyes. Monarquía y religión en Europa, 1589-1715. Madrid: Alianza, 1999.

LANDES, Joan B. Feminism, the Public and the Private. New York: Oxford University Press, 1998.

LANDES, Joan B. Visualizing the Nation. Gender, Representation, and Revolution in the Eighteenth-Century in France. Cornell University Press, 2001.

LÓPEZ-CORDÓN, María Victoria. "La construcción de una Reina en la Edad Moderna: entre el paradigma y los modelos". En: LÓPEZ-CORDÓN, M.V. La Reina Isabel y las reinas de España: realidad, modelos e imagen historiográfica. Actas de la VIII Reunión Científica de la FEHM, Madrid, FEHM, 2005, p. 311.

LÓPEZ-CORDÓN, María Victoria. "Reinas madres, reinas hijas: educación, política y correspondencia en las cortes dieciochescas". Historia y política: Ideas, procesos y movimientos sociales, n. 31, 2014 (Ejemplar dedicado a: Las reinas y la legitimidad de la monarquía en España, siglos XVII-XX), p. 49-80.

LÓPEZ-CORDÓN, María Victoria. "Los estudios históricos sobre las mujeres en la Edad Moderna: estado de la cuestión". Revista de historiografía (RevHisto), n. 22, 2015a (Ejemplar dedicado a: Del ayer al mañana. La historiografía de la historia de las mujeres, del género y del feminismo), p. 147-181.

LÓPEZ-CORDÓN, María Victoria. "Entre Witina y Julia: el viaje intelectual de María Josefa Amalia de Sajonia". En: Los viajes de la Razón. Zaragoza: Institución Fernando el Católico, 2015b, p. 83-101.

MOLINA, Álvaro. "Visualizando el género en la Historia del Arte. El siglo XVIII español como caso de estudio". Anuario del Departamento de Historia y Teoría del Arte, 2012, vol. 24, p. 79-92. 
NOCHLIN, Linda. "Why Have There Been No Great Women Artists?". Art News, 1971, 69, p. 22-39.

NOCHLIN, Linda. Women, Art and Power, and other essays. London: Thames \& Hudson, 1989.

ORACIÓN fúnebre que en las exequias solemnes celebradas en memoria de su amada reyna y señora Doña María Josefa Amalia, ..., por la real archicofradía de nuestro padre Jesús de la Expiación y Nuestra Señora de las Aguas, de la que es hermano mayor nuestro augusto Soberano el rey D. Fernando VII, el domingo 5 de julio de 1829 en la Iglesia del Convento Casa Grande de Mercedarios calzados de esta ciudad. Sevilla: Impreso á expensas de dicha Archicofradía por Hidalgo y Compañía.

PÉREZ SAMPER, María Ángeles. "La figura de la reina en la Monarquía española de la Edad Moderna: poder símbolo y ceremonia". En: LÓPEZ CORDÓN, M. V. La Reina Isabel y las reinas de España: realidad, modelos e imagen historiográfica. Actas de la VIII Reunión Científica de la FEHM, Madrid, FEHM, 2005, p. 275 y 307.

RELACIÓN de las exequias que celebraron los Grandes de España en la Iglesia de S. Isidro el Real de esta corte el día 17 de marzo de 1819 en sufragio de la Reina Nuestra Señora Doña María Isabel Francisca de Braganza (Q.E.E.G.) y oración fúnebre que en ellas dijo el Sr. Licenciado Don Antonio García Bermejo... Madrid: Imprenta de don Miguel de Burgos, 1819.

RODRÍGUEZ DE CÁMARA, Eduardo. Oración Fúnebre que en las solemnes y Reales Honras celebradas de orden de S. M. el Señor D. Fernando VII. Rey de España y de las Indias por el alma de su Augusta Esposa la Señora Doña María Josefa Amalia de Sajonia dijo el P. Eduardo José Rodríguez de Cámara. S.J., 1829.
SALVADOR, José del. Oración fúnebre que en las solem nísimas honras celebradas por la M.N. y L. ciudad de San Sebastián a la Serenísima señora $D^{a}$ María Antonia de Borbón y Lorena Princesa de Asturias, en los días inmediatos a su fallecimiento, que fue en mayo de 1806, dijo... Madrid: Imprenta de Don Francisco de la Parte, 1815.

SCHULTE, Regina (ed.). The Body of the Queen: Gender and Rule in the Courtly World, 1500-2000. Berghahn Books, 2006.

SCHULTE, Regina. "The Queen -a Middle Class Tragedy-: The Writing of History and Creation of Myths in Nineteenth-Century France and Germany". Gender and History, 2002, vol. 14, 2, p. 266-293.

SMITH, Theresa. The Emerging Female Citizen: Gender and Enlightenment in Spain. Berkeley: University of California, 2006.

SUCINTA relacion de las honres fúnebres que a su augusta soberana. Sra. Doña Maria Josefa Amalia Reyna de España (...). Barcelona: Imprenta de Joan Francesc Piferrer, 1829.

TORRES GONZÁLEZ, Begoña. El Amor y la Muerte en el Romanticismo. Fondos del Museo Romántico. Madrid: Ministerio de Educación, Cultura y Deporte, 2001.

UNOWSKY, Daniel L. The Pomp and Politics of Patriotism. Imperial Celebrations in Habsburg Austria, 1848-1916. Purdue University Press, 2005.

WHITE, Shara L. "Liberty, Honor, Order: Gender and Political Discourse in Nineteenth-Century Spain". En: ENDERS, Victoria L.; RADCLIFF Pamela B. (eds.). Constructing Spanish Womanhood. Female Identity in Modern Spain. Albany: State University of New York Press, 1979. 
